Article

\title{
Occurrence, Pathogenicity, and Mycotoxin Production of Fusarium temperatum in Relation to Other Fusarium Species on Maize in Germany
}

\author{
Annette Pfordt ${ }^{1, \dagger}$, Simon Schiwek ${ }^{2, \dagger}$, Anna Rathgeb ${ }^{2}$, Charlotte Rodemann ${ }^{1}$, Nele Bollmann ${ }^{1}$, \\ Matthias Buchholz ${ }^{1}$, Petr Karlovsky ${ }^{2, *}$ id and Andreas von Tiedemann 1,*(D) \\ 1 Plant Pathology and Crop Protection, University of Goettingen, 37077 Goettingen, Germany; \\ annette.pfordt@uni-goettingen.de (A.P.); charlotte.rodemann@stud.uni-goettingen.de (C.R.); \\ nele.bollmann@stud.uni-goettingen.de (N.B.); matthias.buchholz@uni-hohenheim.de (M.B.) \\ 2 Molecular Phytopathology and Mycotoxin Research, University of Goettingen, 37077 Goettingen, Germany; \\ simon.schiwek@uni-goettingen.de (S.S.); annarathgeb@gmail.com (A.R.) \\ * Correspondence: pkarlov@gwdg.de (P.K.); atiedem@gwdg.de (A.v.T.) \\ + These authors contribute equally to this work.
}

Received: 1 October 2020; Accepted: 19 October 2020; Published: 22 October 2020

check for updates

\begin{abstract}
Fusarium subglutinans is a plant pathogenic fungus infecting cereal grain crops. In 2011, the species was divided in Fusarium temperatum sp. nov. and F. subglutinans sensu stricto. In order to determine the occurrence and significance of F. temperatum and F. subglutinans on maize, a monitoring of maize ears and stalks was carried out in Germany in 2017 and 2018. Species identification was conducted by analysis of the translation elongation factor $1 \alpha$ (TEF-1 $\alpha$ ) gene. Ninety-four isolates of F. temperatum and eight isolates of F. subglutinans were obtained during two years of monitoring from 60 sampling sites in nine federal states of Germany. Inoculation of maize ears revealed a superior aggressiveness for F. temperatum, followed by Fusarium graminearum, Fusarium verticillioides, and F. subglutinans. On maize stalks, F. graminearum was the most aggressive species while F. temperatum and F. subglutinans caused only small lesions. The optimal temperature for infection of maize ears with F. temperatum was $24^{\circ} \mathrm{C}$ and $21^{\circ} \mathrm{C}$ for F. subglutinans. All strains of F. temperatum and F. subglutinans were pathogenic on wheat and capable to cause moderate to severe head blight symptoms. The assessment of mycotoxin production of 60 strains of F. temperatum cultivated on rice revealed that all strains produced beauvericin, moniliformin, fusaric acid, and fusaproliferin. The results demonstrate a higher prevalence and aggressiveness of F. temperatum compared to F. subglutinans in German maize cultivation areas.
\end{abstract}

Keywords: Fusarium temperatum; Fusarium subglutinans; pathogenicity; maize ear rot; Fusarium head blight; beauvericin; translation elongation factor $1 \alpha$

\section{Introduction}

Fusarium ear and stalk rot are ubiquitous diseases of maize with high economic impact in agriculture [1]. Several Fusarium species infecting maize are known to produce toxic secondary metabolites, called mycotoxins, which impair grain quality and threaten the safety of animal feed and food products [2,3]. Among the most important Fusarium species inciting pre- and post-harvest ear rot of maize are F. graminearum and F. verticillioides [4-6], but also other species such as Fusarium poae [7,8], Fusarium proliferatum [1], F. subglutinans [9], and F. temperatum [10] are frequently reported. Ear infection is typically characterized by the growth of white or reddish mycelium with rot induced on the cob and on stored grains. 
F. subglutinans, which is a member of the Fusarium fujikuroi species complex (FFSC), predominantly occurs in temperate climate regions. F. subglutinans was elevated to the species level in 1983 by Nelson et al. [11], after separation from F. verticillioides. Later on, in 2002, Steenkamp et al. [12] reported two cryptic species within a set of isolates of F. subglutinans, obtained from several locations, based on phylogenetic concordance analyses of six nuclear regions, and suggested that both subspecies justify separation into two individual taxa. Phylogenetic separation was further supported by mycotoxin analyses revealing the production of beauvericin (BEA), which was exclusively produced by European isolates belonging to the so-called group 1 of F. subglutinans [13]. Furthermore, separation of strains was based on differences in climatic requirements, since isolates of $F$. subglutinans group 1 were frequently collected in cooler regions like Germany, Poland, and Austria while F. subglutinans group 2 prevailed in warmer and dryer regions such as Slovakia, Italy, and Serbia [13]. Several other studies also reported the detection of mycotoxins, such as beauvericin [14,15] fusaproliferin (FUSA) [16], moniliformin (MON) [17], and rarely fumonisin B1 (FB1) [18], produced by the subgroup of F. subglutinans, presumably F. subglutinans group 1. In 2011, this cryptic subgroup was classified as a novel species, establishing F. temperatum as species nova, corresponding to the formerly known group 1 of F. subglutinans [10]. The mycotoxin profile of $F$. temperatum is not yet fully clarified. While the production of beauvericin was consistently found in all strains of $F$. temperatum, moniliformin and fumonisins were produced only by a single isolate of F.temperatum as reported by Scauflaire et al. [19]. Similarly, production of beauvericin, moniliformin, fusaproliferin, and fumonisins was reported for F. temperatum strains from Argentina [20]. Further studies report on F. temperatum infection on maize causing seedling blight and root rot [21] and ear rot, as well as head blight on wheat [22].

The aim of the study was to determine the occurrence of F. temperatum and F. subglutinans on maize ears and stalks in Germany and to assess their pathogenicity relative to each other and to other common Fusarium ear rot and head blight pathogens. In addition, the mycotoxin profiles of F. temperatum and F. subglutinans were compared.

\section{Results}

\subsection{Occurrence of Fusarium Species on Cobs and Stalks}

In 2017 and 2018, ninety-four isolates of F. temperatum and eight isolates of F. subglutinans (Table S1) were obtained from diseased cobs collected across eight federal states of Germany (Figure S1). F. temperatum was isolated from $17 \%$ of all analyzed samples, making it the third most often occurring Fusarium species following F. graminearum (57\%) and F. verticillioides $(22 \%)$ in cobs $(\mathrm{n}=293)$ and the fourth most often isolated species on stalks $(\mathrm{n}=190)$ (Table 1$)$. The frequency of $F$. temperatum isolated from ears ranged from $15 \%$ in 2017 to $21 \%$ in 2018. F. subglutinans was only detected in $2 \%$ of all analyzed cobs, at two locations, and in $3 \%$ of the stalk samples, at one location.

Table 1. Relative occurrence of F. temperatum, F. subglutinans, F. graminearum, and F. verticillioides on naturally infected cobs and stalk samples in the field in 2017 and 2018.

\begin{tabular}{|c|c|c|c|c|c|c|c|c|c|c|}
\hline \multirow{4}{*}{ Fusarium Species } & \multicolumn{5}{|c|}{ Cobs } & \multicolumn{5}{|c|}{ Stalks } \\
\hline & \multicolumn{3}{|c|}{ Infected (\%) } & \multicolumn{2}{|c|}{ Sample Sites } & \multicolumn{2}{|c|}{ Infected (\%) } & \multicolumn{3}{|c|}{ Sample Sites } \\
\hline & \multirow{2}{*}{$\begin{array}{c}2017 \\
n=180\end{array}$} & \multirow{2}{*}{$\begin{array}{c}2018 \\
n=113\end{array}$} & \multirow{2}{*}{ Mean ${ }^{1}$} & \multirow{2}{*}{$\begin{array}{c}2017 \\
n=42\end{array}$} & \multirow{2}{*}{$\begin{array}{c}2018 \\
\mathrm{n}=18\end{array}$} & \multirow{2}{*}{$\begin{array}{c}2017 \\
n=110\end{array}$} & \multirow{2}{*}{$\begin{array}{c}2018 \\
n=80\end{array}$} & \multirow{2}{*}{ Mean ${ }^{1}$} & \multirow{2}{*}{$\begin{array}{c}2017 \\
n=21\end{array}$} & \multirow{2}{*}{$\begin{array}{c}2018 \\
\mathrm{n}=14\end{array}$} \\
\hline & & & & & & & & & & \\
\hline F. temperatum & 15 & 21 & 17 & 21 & 15 & 15 & 20 & 17 & 7 & 13 \\
\hline F. subglutinans & 2 & 2 & 2 & 3 & 3 & 1 & 3 & 2 & 1 & 2 \\
\hline F. graminearum & 71 & 30 & 57 & 41 & 15 & 81 & 43 & 65 & 20 & 11 \\
\hline F. verticillioides & 13 & 39 & 22 & 11 & 16 & 22 & 16 & 19 & 14 & 11 \\
\hline
\end{tabular}

${ }^{1}$ Mean of the percentage of infections in the years 2017 and 2018. 


\subsection{Pathogenicity on Maize Cobs under Field Conditions}

Weather conditions in both years of investigation were conducive for the development of Fusarium ear rot infection at the five field sites. Disease severity was strongly affected by pathogen species, year, inoculation method, location, and maize variety as well as the interactions of all factors. According to the mean of squares, pathogen species effects had the highest impact on disease severity (DS), followed by variety and the interaction of both (Table S2). On the average of field experiments, F. temperatum was the most aggressive species ( $31 \%$ DS), followed by F. graminearum ( $20 \%$ DS), F. subglutinans $(15 \%$ DS), and F. verticillioides (11\% DS) (Table 2). On the average of the four Fusarium species tested, disease severity was favored by silk channel inoculation (26\%) compared to needle pin inoculation (13\%).

Table 2. Disease severity (\%) on maize cobs after inoculation with F. graminearum, F. temperatum, and F. verticillioides in 2018 and 2019 at five locations in Germany and France as well as with F. subglutinans in 2019 in Goettingen using needle or silk channel inoculation.

\begin{tabular}{ccccc}
\hline \multicolumn{5}{c}{ Disease Severity (\%) } \\
\cline { 2 - 5 } & F. graminearum & F. temperatum & F. verticillioides & F. subglutinans \\
\hline 2018 & $28 \pm{ }^{1} 30 \mathrm{a} \mathrm{a}^{2} \mathrm{~B}^{3}$ & $40 \pm 34 \mathrm{aC}$ & $12 \pm 15 \mathrm{aA}$ & - \\
2019 & $15 \pm 22 \mathrm{bC}$ & $25 \pm 26 \mathrm{bD}$ & $11 \pm 20 \mathrm{bA}$ & $15 \pm 19 \mathrm{~B}$ \\
\hline Needle pin & $19 \pm 26 \mathrm{aB}$ & $19 \pm 14 \mathrm{aB}$ & $5 \pm 8 \mathrm{aA}$ & $10 \pm 7 \mathrm{aA}$ \\
Silk channel & $22 \pm 26 \mathrm{aA}$ & $44 \pm 37 \mathrm{bB}$ & $18 \pm 22 \mathrm{bA}$ & $20 \pm 25 \mathrm{bA}$ \\
\hline Bernburg & $25 \pm 28 \mathrm{cB}$ & $30 \pm 31 \mathrm{bC}$ & $9 \pm 19 \mathrm{aA}$ & - \\
Kuenzing & $21 \pm 25 \mathrm{bcB}$ & $37 \pm 30 \mathrm{bC}$ & $13 \pm 19 \mathrm{aA}$ & - \\
Liesborn & $18 \pm 22 \mathrm{bB}$ & $37 \pm 35 \mathrm{bC}$ & $11 \pm 19 \mathrm{aA}$ & - \\
Rustenhart & $27 \pm 29 \mathrm{cB}$ & $32 \pm 27 \mathrm{bC}$ & $12 \pm 14 \mathrm{aA}$ & - \\
Goettingen & $14 \pm 24 \mathrm{aA}$ & $21 \pm 27 \mathrm{aB}$ & -4 & $15 \pm 19 \mathrm{~A}$ \\
\hline MEAN & $20 \pm 26 \mathrm{~B}$ & $31 \pm 31 \mathrm{C}$ & $11 \pm 18 \mathrm{~A}$ & $15 \pm 19 \mathrm{~A}$ \\
\hline
\end{tabular}

${ }^{1}$ Plus-minus sign ( \pm ) represents variation according to standard deviation. ${ }^{2}$ Small letters indicate significant differences between treatments $(p \leq 0.05) .{ }^{3}$ Capital letters indicate differences $(p \leq 0.05)$ between Fusarium species.

${ }^{4}$ No data has been collected.

\subsection{Pathogenicity on Maize Stalks under Greenhouse Conditions}

Under greenhouse conditions, F. graminearum, Fusarium crookwellense (syn. Fusarium cerealis), Fusarium culmorum, F. temperatum, and F. subglutinans were able to induce necrotic lesions in the stem tissue and on the surface of the stalks after needle pin inoculation. F. graminearum was the most aggressive species on stalks, according to the internal and external lesion length, followed by F. crookwellense and F. culmorum. Severity of infection, recorded as lesion length, was significantly higher with F. graminearum than with F. temperatum and F. subglutinans (Table 3).

Table 3. Lesion length inside the stalk and on the stalk surface of maize at $\mathrm{BBCH} 80,35$ days post inoculation with F. graminearum, F. crookwellense, F. culmorum, F. temperatum, F. subglutinans, and control. Different letters indicate significant differences between treatments $(p \leq 0.05)$.

\begin{tabular}{ccc}
\hline Inoculated Species & Lesion Length inside the Stalk $(\mathbf{m m})$ & Lesion Length on the Stalk Surface $(\mathbf{m m})$ \\
\hline F. graminearum & $78.3 \pm{ }^{1} 4.1 \mathrm{c}$ & $57.7 \pm 2.5 \mathrm{c}$ \\
F. crookwellense & $75.5 \pm 3.7 \mathrm{bc}$ & $43.6 \pm 1.6 \mathrm{bc}$ \\
F. culmorum & $65.7 \pm 3.6 \mathrm{bc}$ & $40.9 \pm 1.7 \mathrm{~b}$ \\
F. temperatum & $55.5 \pm 1.4 \mathrm{~b}$ & $38.0 \pm 1.3 \mathrm{~b}$ \\
F. subglutinans & $53.0 \pm 1.9 \mathrm{~b}$ & $32.7 \pm 0.9 \mathrm{~b}$ \\
Control & $17.7 \pm 0.6 \mathrm{a}$ & $15.0 \pm 1.1 \mathrm{a}$ \\
\hline MEAN & $58 \pm 3.4 \mathrm{~B}$ & $37 \pm 2.0 \mathrm{~A}$ \\
\hline
\end{tabular}


All F. temperatum and F. subglutinans isolates were able to cause typical symptoms of stalk rot in maize after toothpick inoculation on 49-days old plants (Table 4). Necrotic lesions caused by individual isolates significantly differed from the control treatment. Lesion lengths inside the stalk ranged from $15 \mathrm{~mm}$ to $45 \mathrm{~mm}$ and outside the stalk from $10 \mathrm{~mm}$ to $20 \mathrm{~mm}$. Lesions induced by infection with F. temperatum were significantly longer than after inoculation with $F$. subglutinans.

Table 4. Lesion length inside the stalk and on the surface of maize stalks 14 days post inoculation in the greenhouse with eight strains of $F$. subglutinans and fourteen strains of F. temperatum compared to a water control. Different letters indicate significant differences between treatments $(p \leq 0.05)$.

\begin{tabular}{|c|c|c|}
\hline Isolate & Lesion Length inside the Stalk (mm) & Lesion Length on the Stalk Surface (mm) \\
\hline \multicolumn{3}{|c|}{ Control } \\
\hline Water & $3.4 \pm{ }^{1} 0.4 \mathrm{aA}$ & $3.6 \pm 0.4 \mathrm{aA}$ \\
\hline \multicolumn{3}{|c|}{ F. subglutinans } \\
\hline Fs 187.1 & $15.5 \pm 1.1 \mathrm{~b}$ & $10.3 \pm 0.5 b$ \\
\hline Fs 262.1 & $16.3 \pm 0.5 \mathrm{abc}$ & $10.3 \pm 0.5 \mathrm{ab}$ \\
\hline Fs 126.2 & $22.9 \pm 1.1 \mathrm{bc}$ & $13.0 \pm 0.8 \mathrm{~b}$ \\
\hline Fs 215.6 & $24.3 \pm 0.5 \mathrm{bc}$ & $11.2 \pm 0.2 b$ \\
\hline Fs 209.4st & $25.7 \pm 0.8 \mathrm{bc}$ & $11.5 \pm 0.2 b$ \\
\hline Fs 261.2 & $27.8 \pm 1.3 c$ & $11.8 \pm 0.2 \mathrm{~b}$ \\
\hline Fs $28.4 \mathrm{sp}$ & $28.0 \pm 1.2 \mathrm{c}$ & $20.8 \pm 0.6 c$ \\
\hline MEAN & $22.7 \pm 1.5 \mathrm{~B}$ & $13.1 \pm 0.6 \mathrm{~B}$ \\
\hline \multicolumn{3}{|c|}{ F. temperatum } \\
\hline Ft 18.5 & $19.6 \pm 1.4 \mathrm{~b}$ & $8.8 \pm 0.4 \mathrm{ab}$ \\
\hline Ft 22.4st & $25.5 \pm 1.7 b c$ & $8.8 \pm 0.3 \mathrm{ab}$ \\
\hline Ft 184.2 & $28.2 \pm 1.5 \mathrm{bc}$ & $20.8 \pm 1.3 c$ \\
\hline Ft 106.4st & $30.2 \pm 1.5 \mathrm{bcd}$ & $14.2 \pm 0.9 \mathrm{bc}$ \\
\hline Ft 98.4st & $30.4 \pm 1.4 \mathrm{bcd}$ & $16.7 \pm 0.8 \mathrm{bc}$ \\
\hline Ft 65.2 & $30.5 \pm 1.3 \mathrm{bcd}$ & $15.8 \pm 0.5 b c$ \\
\hline Ft 188.2 & $30.8 \pm 1.5 \mathrm{bcd}$ & $17.7 \pm 1.2 \mathrm{bc}$ \\
\hline Ft 91.1st & $32.3 \pm 1.3 \mathrm{bcd}$ & $16.2 \pm 0.7 b c$ \\
\hline Ft 81.4st & $33.3 \pm 1.7 \mathrm{bcd}$ & $16.1 \pm 0.3 b c$ \\
\hline Ft 127.2sp & $33.2 \pm 1.2 \mathrm{bcd}$ & $18.8 \pm 0.9 c$ \\
\hline Ft 99.3st & $39.0 \pm 1.9 \mathrm{~cd}$ & $19.9 \pm 0.9 c$ \\
\hline Ft 100.3st & $41.1 \pm 1.3 \mathrm{~cd}$ & $12.9 \pm 0.7 b c$ \\
\hline Ft 50.2 & $45.4 \pm 1.4 \mathrm{~d}$ & $20.8 \pm 1.0 c$ \\
\hline MEAN & $32.3 \pm 1.6 \mathrm{C}$ & $15.9 \pm 0.9 \mathrm{C}$ \\
\hline
\end{tabular}

${ }^{1}$ Plus-minus sign ( \pm ) represents variation according to standard deviation.

\subsection{Effect of Temperature on Ear Infection}

The temperature had a significant $(p \leq 0.05)$ effect on disease severity of both F. temperatum and F. subglutinans. The highest contribution to the variance of disease severity originated from the varieties, followed by the interaction of temperature and fungal isolate (Table S3). Inoculation with F. subglutinans caused the highest disease severity on kernels $(23 \%)$ and rachis $(46 \%)$ at $21^{\circ} \mathrm{C}$. However, the highest disease severity caused by F. temperatum on kernels (24\%) and rachis (20\%) occurred at $24{ }^{\circ} \mathrm{C}$ (Figure 1 ). 
Kernels

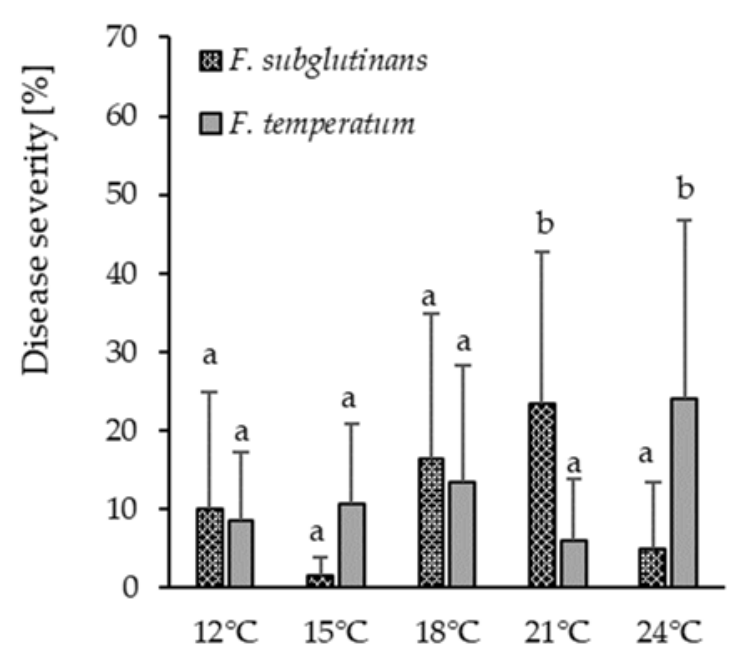

(a)

\section{Rachis}

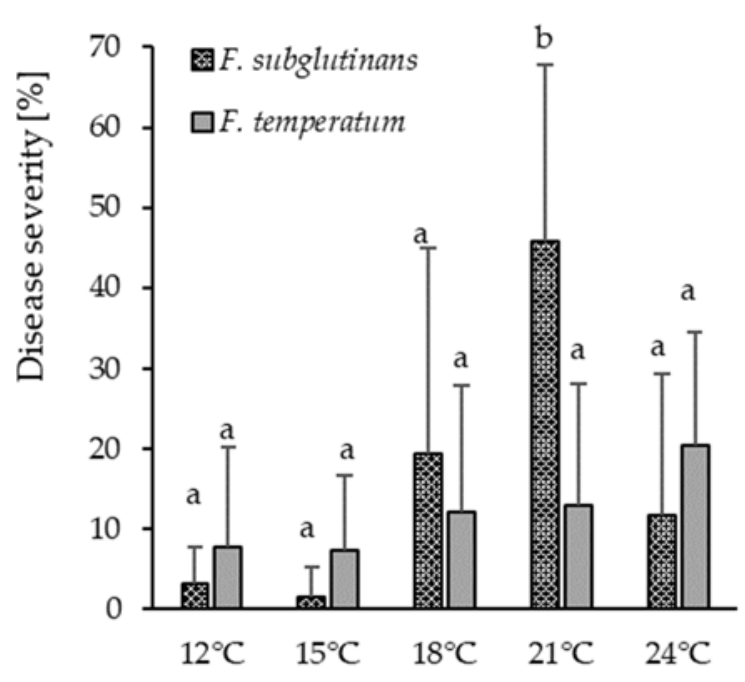

(b)

Figure 1. Disease severity induced by F. subglutinans and F. temperatum at $12{ }^{\circ} \mathrm{C}, 15^{\circ} \mathrm{C}, 18{ }^{\circ} \mathrm{C}, 21^{\circ} \mathrm{C}$, and $24{ }^{\circ} \mathrm{C}$ on kernels (a) and rachis (b) of maize cobs. Vertical bars represent standard deviations. Different letters indicate significant differences $(p \leq 0.05)$.

\subsection{Pathogenicity on Wheat under Greenhouse Conditions}

All F. subglutinans and F. temperatum isolates were able to infect winter wheat and to cause symptoms of Fusarium head blight (Table 5). The highest disease severity was caused 21 days after infection by F. graminearum ( $52 \%$ ), followed by F. temperatum (44\%) and F. subglutinans (40\%). However, no significant differences were observed between $F$. graminearum and $F$. temperatum regarding disease severity and kernel weight.

Table 5. Disease severity and thousand-kernel weight (TKW) of winter wheat inoculated in the greenhouse at flowering stage with three different Fusarium species. Different letters indicate significant differences within the columns ( $p \leq 0.05)$.

\begin{tabular}{ccccc}
\hline \multirow{2}{*}{ Species } & \multicolumn{3}{c}{ Disease Severity (\%) } & \multirow{2}{*}{ TKW (g) } \\
\cline { 2 - 4 } & $\mathbf{7} \mathbf{d p i}^{\mathbf{1}}$ & $\mathbf{1 4} \mathbf{d p i}$ & $\mathbf{2 1} \mathbf{d p i}$ & \\
\hline Control & $3 \pm{ }^{2} 6 \mathrm{a}$ & $10 \pm 11 \mathrm{a}$ & $17 \pm 15 \mathrm{a}$ & $33 \pm 10 \mathrm{a}$ \\
F. subglutinans & $7 \pm 8 \mathrm{ab}$ & $19 \pm 15 \mathrm{~b}$ & $40 \pm 23 \mathrm{~b}$ & $34 \pm 7 \mathrm{a}$ \\
F. temperatum & $7 \pm 6 \mathrm{~b}$ & $18 \pm 12 \mathrm{bc}$ & $44 \pm 24 \mathrm{bc}$ & $33 \pm 7 \mathrm{ab}$ \\
F. graminearum & $12 \pm 11 \mathrm{~b}$ & $28 \pm 18 \mathrm{c}$ & $52 \pm 29 \mathrm{c}$ & $27 \pm 5 \mathrm{~b}$ \\
\hline${ }^{1}$ Days post inoculation (dpi). ${ }^{2}$ Plus-minus sign ( \pm ) represents variation according to standard deviation.
\end{tabular}

\subsection{Differential Identification of F. temperatum and F. subglutinans}

Differential identification of species in the Fusarium fujikuroi species complex (FFSC) (F. temperatum, F. subglutinans, F. verticillioides, and F. proliferatum, ) was performed by species-specific PCR. A total number of 161 single-spore cultures isolated from naturally infected maize cobs and stalk samples in 2018 and grown in PDB were used to extract genomic DNA. The specificity of primers was validated in the studies in which they were designed (references in Table S6). Primers specific for F. temperatum allowed amplification of the expected DNA fragments in 44 samples of $F$. temperatum, while samples obtained from pure cultures of F. subglutinans, F. verticillioides, and F. proliferatum did not show amplification. Primers SUB1/SUB2 (Table S7), designed for the amplification of DNA from F. subglutinans [23], also generated amplicons in all samples of F. temperatum but did not amplify 
F. verticillioides or F. proliferatum. Three samples were identified as F. subglutinans, as they showed no amplification with primers specific for $F$. temperatum but were positive in the species-specific assay for F. subglutinans. Primers for F. verticillioides and F. proliferatum, the specificity of which has been extensively validated [24], enabled the differential identification of these species in 66 and 48 isolates, respectively.

Following amplification and sequencing of $T E F-1 \alpha$, partial nucleotide sequences (601 bp) from pre-identified isolates of $F$. temperatum and F. subglutinans were aligned with additional references of F. verticillioides, F. proliferatum, and Fusarium pseudograminearum using ClustalW [25] in MEGA7 [26] (Figure 2). All sequences of F. temperatum $(\mathrm{n}=72)$ and F. subglutinans $(\mathrm{n}=7)$ clustered into two groups. The separation between F. temperatum and F. subglutinans was based on 20 single nucleotide polymorphisms (SNP) within TEF-1 $\alpha$. We found 30 isolates of $F$. temperatum with $100 \%$ sequence identity with the reference strain MUCL52436, 24 isolates with the same TEF-1 $\alpha$ sequences as MUCL52450, 5 isolates with TEF-1 $\alpha$ identical with MUCL52445 and 4 isolates with TEF- $1 \alpha$ sequence identical with MUCL52454. These sequences formed a separate clade in the phylogenetic tree (Figure 2). Only six samples, identical in their sequence to MUCL52462, were grouped in a further separate clade. The assignments of isolates to individual reference strains are presented in more detail in Table S4. The differentiation among the isolates of F. temperatum was mostly based on single SNPs. Thus, despite resampling a relatively uniform population, the phylogenetic analysis showed that isolates of F. temperatum can be further divided into two subgroups, which was strongly supported by bootstrap values. Group 1 included the majority of 68 sequences, sharing a high sequence similarity with the reference strains MUCL52436 and MUCL52450. Group 2 is represented by only seven sequences, including MUCL52462. Sequence variation was observed at five positions within the segment of $T E F-1 \alpha$, further dividing the species in six genotypes. The grouping within the F. subglutinans clade was not supported by bootstrapping.

Analysis of partial RPB2 was performed for a subset of six isolates, representing the two clades that were observed during investigation of TEF-1 $\alpha$. All tested isolates were assigned to a single phylogenetic group, together with reference strain MUCL52463 (Figure S2). Newly obtained sequences were submitted to Genbank; the accession numbers are provided in Tables S1 and S5. 


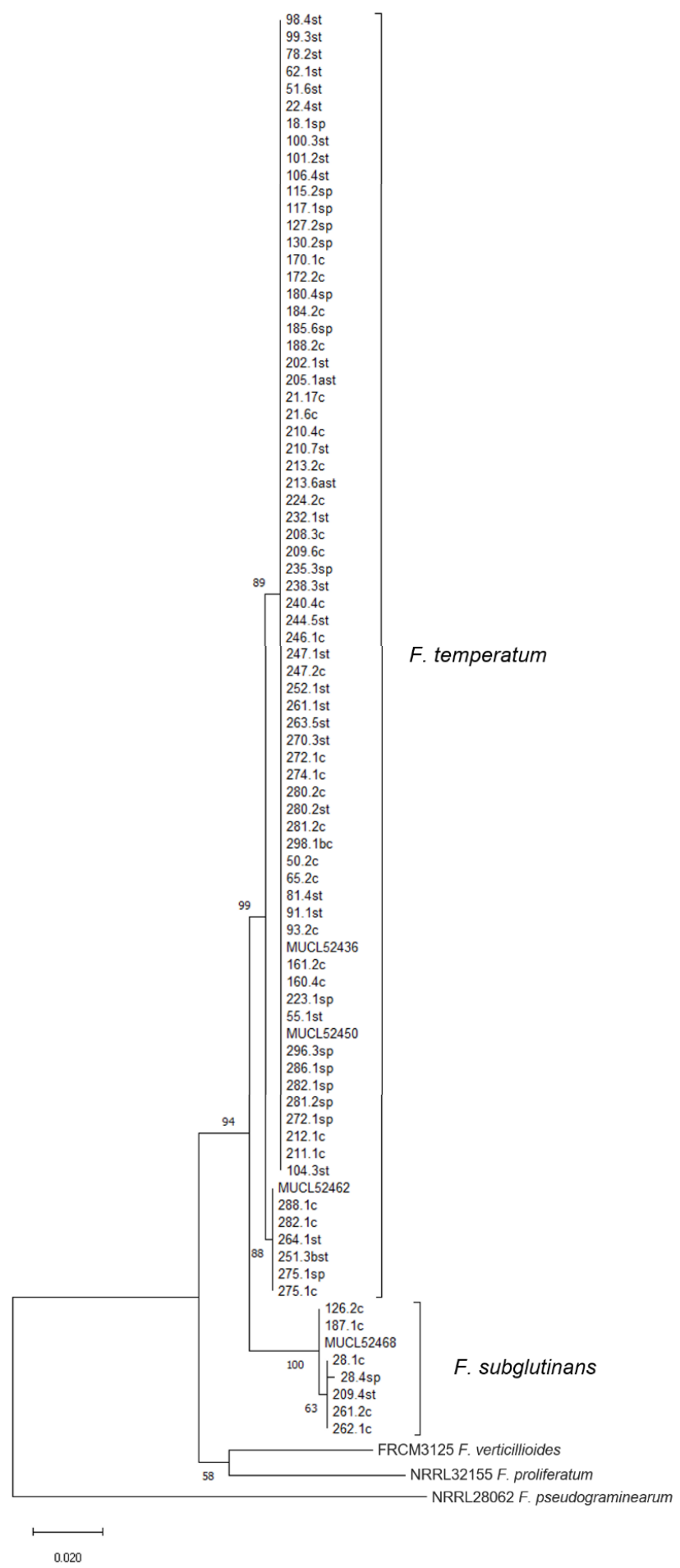

Figure 2. Molecular phylogenetic analysis of translation elongation factor 1 alpha (TEF-1 $\alpha)$ by the maximum likelihood method (1000 bootstrap replicates) [27]. Analysis was performed with ClustalW [25] in MEGA version 7.0.26 [26] with partial TEF-1 $\alpha$ sequences of 72 isolates of F. temperatum and 7 isolates of F. subglutinans (Table S3), and references for F. temperatum MUCL52436, MUCL52450, MUCL52462, and F. subglutinans MUCL52468 [10]. We added additional references for F. proliferatum NRRL32155, F. verticillioides FRCM3125, and F. pseudograminearum NRRL26062 to scale phylogenetic separation. The tree is drawn to scale, with branch lengths measured in the number of substitutions per site. Bootstrap values are presented next to the nodes. Nucleotide sequences have been subjected to Genbank, the accession numbers are presented in Tables S1 and S5. 


\subsection{Mycotoxin Analysis}

We tested 61 isolates of $F$. temperatum and six isolates of F. subglutinans, obtained from 67 naturally infected maize cobs or stalk samples (limited to a single isolate per sample to prevent repeated isolation of the same strains), in cultures of polished rice for the production of the following mycotoxins: fumonisin B1 (FB1), fumonisin B2 (FB2), beauvericin (BEA), fusaric acid (FA), moniliformin (MON), enniatin B (ENNB), enniatin A1 (ENNA1), and fusaproliferin (FUSA). Furthermore, the reference strain MUCL52463 (F. temperatum) and isolates of F. verticillioides and F. proliferatum, identified by sequencing of partial nucleotide sequence of TEF-1 $\alpha$ (Section 2.6), were included because they have distinct mycotoxin profiles. The results are summarized in Table 6. F. temperatum isolates only produced BEA, FA, MON, and FUSA. In F. subglutinans, FA, MON, and FUSA but no BEA were detected in all cultures. One isolate of F. temperatum and one isolate of F. subglutinans produced FB1 and FB2, similarly to F. verticillioides and F. proliferatum, but the results likely resulted from a contamination because the strains did not possess the fumonisin biosynthetic gene FUM1 [28] (see below). Rice cultures of $F$. verticillioides and F. proliferatum accumulated FB1, FB2, and FUSA, while BEA, FA, and MON were only produced by F. proliferatum. No enniatins (ENNB or ENNA1) were detected in any of the analyzed cultures.

Table 6. Mycotoxin production in rice cultures of F. temperatum, F. subglutinans, F. verticillioides, and F. proliferatum, isolated from naturally infected maize cobs and stalk samples.

\begin{tabular}{|c|c|c|c|c|c|c|c|c|}
\hline \multirow{2}{*}{ Species } & \multirow{2}{*}{ No. of Isolates } & \multicolumn{7}{|c|}{ Toxins } \\
\hline & & FB1 & FB2 & BEA & FA $^{3}$ & MON & FUSA $^{4}$ & ENNs $^{5}$ \\
\hline F. temperatum ${ }^{6}$ & 60 & -1 & - & ++2 & ++ & ++ & yes & - \\
\hline F. subglutinans 6 & 5 & - & - & - & +2 & + & yes & - \\
\hline F. verticillioides & 4 & +++ & +++ & - & - & - & yes & - \\
\hline F. proliferatum & 4 & +++ & +++ & + & + & ++ & yes & - \\
\hline
\end{tabular}

${ }^{1}$ Metabolite could not be detected (values were below LOD, Table S6). ${ }^{2}$ Average concentration of mycotoxins (FB1, FB2, BEA, MON, ENNB, ENNA1): +++ more than $1 \mathrm{~g} / \mathrm{kg},++0.1$ to $1.0 \mathrm{~g} / \mathrm{kg}$, + less than $100 \mathrm{mg} / \mathrm{kg}$. ${ }^{3}$ Average for FA concentration: +++ more than $10 \mathrm{mg} / \mathrm{kg}$, ++ 1 to $10 \mathrm{mg} / \mathrm{kg}$, + less than $1 \mathrm{mg} / \mathrm{kg}$. ${ }^{4}$ FUSA was qualitatively evaluated; yes, indicates the presence of FUSA in the tested sample. ${ }^{5}$ ENNB and ENNA1. ${ }^{6}$ Fumonisins were detected in a single culture of each F. temperatum and F. subglutinans (see main text).

\subsection{Search for FUM1-analogues in F. temperatum and F. subglutinans}

The capacity to produce fumonisins was investigated by the amplification and sequencing of a segment of the FUM1 gene. In a set of isolates, including four isolates of F. temperatum and one isolate of $F$. subglutinans that appeared to produce fumonisins in vitro, we sequenced the DNA fragment amplified using primers FUM1F1 and FUM1R2, designed by Stepien et al. for the FUM1 gene [28]. The amplicons were approximately $860 \mathrm{bp}$ long. Amplification of DNA from two randomly chosen isolates of F. verticillioides and F. proliferatum yielded a single fragment of about $1.1 \mathrm{~kb}$ from each isolate. Sequencing and BLAST-analysis revealed the identity of the latter with the gene FUM1 in F. verticillioides (KC188787.1) and F. proliferatum (KU180047.1), encoding a polyketide synthase. No similarity at nucleotide or amino acid sequences level could be found between the amplicons generated from F. temperatum, F. subglutinans DNA with the primers FUM1F1/FUM1R2 [28], and the genomes of F. verticillioides or F. proliferatum. We also tried out primers Rp32: 5'-ACAAGTGTCCTTGGGGTCCAGG-3' and Rp33:5'-GATGCTCTTGGAAGTGGCCTACG-3', specific for the amplification of the FUM1 gene from F. verticillioides [29], but we could not amplify the gene from F. temperatum or F. subglutinans.

Multiple alignment of the sequences revealed high similarity between the genes from F. subglutinans and F. temperatum, yet no obvious similarity with the FUM1 gene (Figure 3). Search of NCBI database (BLASTX [30]) with the combined nucleotide data set for four isolates of F. temperatum (50.2c, 93.2c, 202.1st, and 264.1st) and one isolate of F. subglutinans (262.1c) as a query yielded a single hit in the recently published whole genome shotgun of Fusarium anthophilum (strain NRRL 25214). The respective gene of $F$. anthophilum was assigned to a hypothetical protein FANTH_8583. The newly sequenced gene loci in F. temperatum and F. subglutinans, amplified with primers FUM1F1 and FUM1R2, 
designed by Stepien et al. [28], were tentatively named FTEMP8583 and FSUBG8583, respectively. Following translation, the amino acid sequences were tested for similarity to known protein domains using the SMART-tool [31]. No similar protein domain was found but a putative coiled coil region was identified. The region started at position 32 and ended at position 68 in the sequences of F. temperatum, and started at position 11 and ended at position 47 in the sequences of F. subglutinans. The alignment of amino acid sequences is presented in Figure 3. All nucleotide sequences have been subjected to Genbank; the accession numbers are presented in Table S1.

Coiled coil region

F.anthophilum F.subglutinans $262.1 \mathrm{C}$

F.temperatum $50.2 \mathrm{C}$

F.temperatum $93.2 \mathrm{C}$

F.temperatum $93.2 \mathrm{C}$

F.temperatum 264.1st

F.anthophilum

F.subglutinans_262.1c

F.temperatum_ $5 \overline{0} .2 \mathrm{C}$

F.temperatum_93.2c

F.temperatum_202.1st

F.temperatum_264.1st

F.anthophilum

F.subglutinans 262.1

F.subglutinans 262 .

F.temperatum_50.2C

F.temperatum_ $93.2 \mathrm{C}$

F.temperatum_264.1st

F.anthophilum

F.subglutinans 262.1C

F.temperatum_50.2C

F.temperatum_93.2C

F.temperatum_202.1st

F.temperatum-264.1st

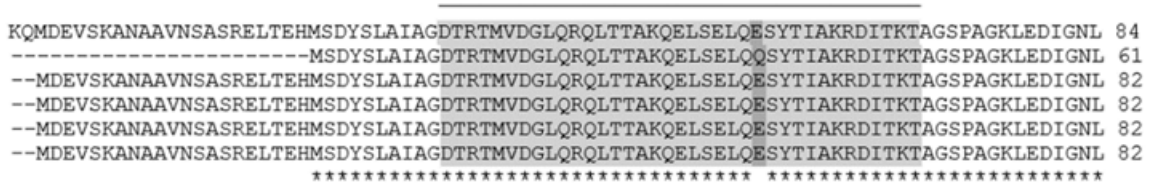

PPGNGGSRWNEIHVKSNVSNDYTKSMKEËGSKVEDFNCNFWIGSYSKNESESQAKVASDSGSNTLSIDVSMRVTYVTVDRNCNF 168 PPGNGGSRWNEVHVKSNVSNDYTKSMKEAGSKVEDFNCNFWIGSYSKNESESQAKVASDSGSNTLSIDVSMRVTYVTVDRNCNF 145 PPGNGGSRWNEVHVKSNVSNDYTKSMKEAGSKVEDFNCNFWIGSYSKNESESQAKVASDSGSNTLSIDVSMRVTYVTVDRNCNF 166 PPGNGGSRWNEVHVKSNVSNDYTKSMKEAGSKVEDFNCNFWIGSYSKNESESQAKVASDSGSNTLSIDVSMRVTYVTVDRNCNF 166 PPGNGGSRWNEVHVKSNVSNDYTKSMKEAGSKVEDFNCNFWIGSYSKNESESQAKVASDSGSNTLSIDVSMRVTYVTVDRNCNF 166 PPGNGGSRWNEVHVKSNVSNDYTKSMKEAGSKVEDFNCNFWIGSYSKNESESQAKVASDSGSNTLSIDVSMRVTYVTVDRNCNF 166

WIGSYSKNESESQAKVASDSGSNTLSIDVSMRVTYVTVDRSGWFDPÄLLEMSKSFMKGSKTNDYTPWTSWKTGḦKIEDAAKAIT 252 WIGSYSKNESESQAKVASDSGSNTLSIDVSMRVTYVTVDRSGWFDP SLLEMSKSFMKGSKTNDYTPWTSWKTGPKIEDAAKAIT 229 WIGSYSKNESESQAKVASDSGSN LSIDVSMRVTYVVDRS WFDP SLLMSKSFMKGSKTNDYTWTSWKTGPKIEDAAKAIT 250 WIGSYSKNESESQAKVASDSGSNTLSIDVSMRVTYVTDRSGWFDPSLLEMSKSFMGSKTNDYTPWTSWKTGPKIEDAAKAIT 250 WIGSYSKNESESQAKVASDSGSNTLSIDVSMRVTYVTVDRSGWFPSLLEMSKSFMKGSKTNDYTPWTSWKTGPKIEDAAKAIT 250 WIGSYSKNESESQAKVASDSGSNTLSIDVSMRVTYVTVDRSGWFDPSLLEMSKSFMKGSKTNDYTPWTSWKTGPKIEDAAKAIT 250

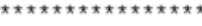

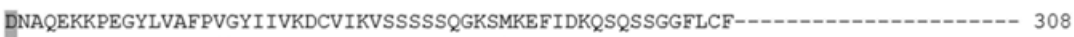
DNAQEKKPEGYLVAFPVGYIIVKDCVIKVSSSSSQGKSMKEFIDKQSQSSGGFLCFSHSSASRSSSDSSSSSTTSASD 307 DNAQEKKPEGYLVAFPVGYIIVKDCVIKVSSSSSQGKSMKEFIDKQSQSSGGFLCFSHSSASRSSSDSSSSSTTSASD 328 ENAQEKKPEGYLVAFPVGYIIVKDCVIKVSSSSSOGKSMKEFIDKOSQSSGGFLCESHSSASRSSSDSSSSSTTSASD 328 DNAQEKKPEGYLVAFPVGYIIVKDCVIKVSSSSSOGKSMKEFIDKOSQSSGGFLCFSHSSASRSSSDSSSSSTTSASD 328

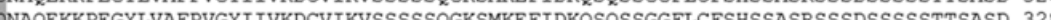
DNAQEKKPEGYLVAFPVGYIIVKDCVIKVSSSSSQGKSMKEFIDKQSQSSGGFLCFSHSSASRSSSDSSSSSTTSASD 328

Figure 3. Comparison of the amino acid sequence of a putative FUM1 analogous gene locus in F. anthophilum (FANTH8583), F. temperatum (FTEMP8583), and F. subglutinans (FSUBG8583). Alignment of amino acid sequences and reference with highest nucleotide sequence similarity after BLASTx search: F. anthophilum NRRL25214 (Accession: JABEVY010000206.1). Light grey was used to highlight a coiled coil region, inferred from SMART-analysis [31]. Dark grey highlights amino acid residues differing among the sequences. The alignment was made with ClustalOmega [32]. Symbol* below the alignment indicates identical amino acids residues. Nucleotide sequences were submitted to Genbank; accession numbers are provided in Tables S1 and S5.

\section{Discussion}

In the monitoring of 2017 and 2018, F. temperatum was found to be the third most often occurring Fusarium species on maize cobs in Germany. Among all samples, $17 \%$ of cob and $17 \%$ of stalk samples were infected with F. temperatum while only $2 \%$ samples were infected with F. subglutinans. Similar findings have recently been reported from several European countries, including Poland [33], France [34], and Belgium [10], as well as China [22] and South Korea [35].

Environmental factors like precipitation and humidity are known to strongly affect the occurrence and disease severity of several Fusarium species [1,11,36,37]. During the two years of monitoring, weather conditions in July differed considerably. In 2017, high precipitation (110.4 mm) occurred and mean temperatures were around $18.8^{\circ} \mathrm{C}$, while in 2018 precipitation was low $(40.4 \mathrm{~mm})$ and temperatures were high $\left(20.6^{\circ} \mathrm{C}\right)$. Nonetheless, the frequency of $F$. subglutinans did not change between the years, while the occurrence of F. temperatum slightly increased in 2018, suggesting warmer temperatures and low precipitation to be favorable for the latter. Similar tendencies were observed in the inoculation experiments in climate chambers. Disease severity on ears inoculated with F. temperatum was highest at $24^{\circ} \mathrm{C}$, while infection with F. subglutinans peaked at $21^{\circ} \mathrm{C}$. Even before F. temperatum and F. subglutinans were defined as individual species, Moretti et al. [13] suggested that a 
separation into two subgroups may be based on different temperature and humidity requirements, which may have resulted from physiological changes in their sites of origin. Similarly, numerous studies related the occurrence of F. temperatum and F. subglutinans to temperature and humidity conditions. Moretti et al. [13] observed that F. subglutinans occurred more often in warmer and drier regions such as Italy, Slovakia, and Serbia, while F. temperatum was reported more often from Germany, Poland, Austria, and Switzerland. These findings correspond to several studies from Belgium [10], China [22] and Argentina [20] indicating higher frequencies of F. temperatum in moderate to cool and moist regions with mean temperatures of $18{ }^{\circ} \mathrm{C}$ or lower, while other studies reported F. temperatum more often in Poland [33] and Germany [38] following dry conditions. Marin et al. [39] demonstrated that the growth rate of most Fusarium ssp. increased with increasing water activity $\left(\mathrm{a}_{\mathrm{w}}\right.$ value); however, the growth rate of F. proliferatum and F. subglutinans decreased at $25^{\circ} \mathrm{C}$ when the $\mathrm{a}_{\mathrm{w}}$ value increased from 0.980 to 0.995 . Further studies are needed to clarify the effect of temperature and precipitation on the occurrence of and disease incidence caused by F. temperatum and F. subglutinans.

Field inoculation studies at five locations in Germany in 2017 and 2018 showed F. temperatum to be the most aggressive Fusarium species in maize, even as compared to F. graminearum and F. verticillioides. However, no significant differences in pathogenicity were observed between F. temperatum and F. subglutinans at a field site in 2018. This observation confirms the particular importance of F. temperatum as an ear rot pathogen in maize cultivation in Germany and other locations with similar climate. The low visual infection rate of F. verticillioides may be explained by symptomless infection and endophytic colonization of maize ears; therefore, disease symptoms may not reflect plant colonization and mycotoxin concentration accurately [40-43].

Inoculation of maize stalks with toothpicks showed that F. temperatum and F. subglutinans are pathogenic on the stalks. However, compared to common stalk rot pathogens like F. graminearum, F. culmorum, and F. crookwellense, disease severity was relatively low. This corresponds to the results of Levic et al. [44] and Scauflaire et al. [19], who reported the formation of necrotic lesions and symptoms like wilting, stunting, and rotting on stalks and leaf sheaths by F. temperatum and F. subglutinans yet lower disease severity as compared to F. crookwellense, F. verticillioides, F. culmorum, and F. graminearum [21].

Crop residues of maize infected with Fusarium spp. are considered a major inoculum source for Fusarium diseases in small grain cereals in Europe, such as seedling and root rot at the seedling stage and Fusarium head blight during anthesis $[45,46]$. Fusarium head blight of wheat is mainly caused by F. graminearum, F. culmorum, F. poae, Fusarium tricinctum, and Fusarium avenaceum [47-49]. In addition, F. subglutinans was reported to rarely infect wheat, causing contamination with MON in small grain cereals from central to north-east European countries [48,50]. F. proliferatum occasionally infects wheat, causing contamination with fumonisins and BEA [51,52]. In our study, all F. temperatum and F. subglutinans isolates were able to infect winter wheat and cause Fusarium head blight at anthesis. The severity of disease caused by F. graminearum was highest and the colonization of the plant advanced with the highest rate, while 21 days post infection no significant differences between F. temperatum and F. graminearum were found with regard to disease severity and thousand-kernel weight. In line with our results, the investigations of Wang et al. [22] demonstrated pathogenicity of F. temperatum and F. subglutinans on wheat; however, the aggressiveness of tested strains was significantly lower than the aggressiveness of a control strain of Fusarium asiaticum.

Identification of F. temperatum and F. subglutinans was carried out by species-specific PCR assays [23,53] and strengthened by the analysis of the marker gene TEF-1 $\alpha$, as previously reported [10]. Phylogenetic analysis enabled the assignment of all obtained isolates to their respective species, as supported by bootstrap values. Separation of isolates and references suggest a rather uniform population of $F$. temperatum, when compared with phylogenetic investigations recently published $[9,34,36,54-56]$. The analysis showed that the isolates of F. temperatum are genetically divided into two groups, as supported by a high bootstrap values. This has also been reported by Shin et al. [55] for isolates of F. temperatum from Korea, even though the isolates were obtained from a single location. We were unable to link this grouping to morphological characteristics nor to mycotoxin profiles of the 
respective isolates. The analysis of TEF-1 $\alpha$ is highly recommended for taxonomical identification of species in the genus Fusarium but reliable separation shall be verified by the investigation of additional informative loci [57]. Hence, we selected the gene for the DNA-directed RNA polymerase II subunit (RPB2) for verification of distinct groups that we observed in the analysis of TEF-1 $\alpha$. The formation of clades could not be reproduced with RPB2 amplified according to Lofgren et al. [58], using a $763 \mathrm{bp}$ portion of the gene located at the $5^{\prime}$ end. The associated phylogram, based on multiple sequence alignments for a small set of isolates and reference strains, is provided in Figure S2. Therefore, we assume that the grouping of nucleotide sequences of TEF-1 $\alpha$ does not reflect the genetic relatedness among the strains.

In order to evaluate the risk of mycotoxin contamination upon infection with F. temperatum and F. subglutinans, in vitro cultures were screened for the presence of eight mycotoxins (BEA, MON, FA, FUSA, ENNB, ENNA1, FB1, and FB2), selected according to Scauflaire et al. [19] and others [14,17,18]. We detected BEA in 58 cultures exclusively of F. temperatum, supporting the suitability of BEA production for the separation of F. temperatum from F. subglutinans, similarly as BEA production separated F. verticillioides from F. proliferatum [24]. The production of MON, FA, and FUSA was confirmed in almost all tested cultures of F. temperatum and F. subglutinans. Previous studies suggested that MON may not be produced universally by F. temperatum [19]. Based on our results, both F. temperatum and F. subglutinans produced MON but the amounts varied among isolates. The production of MON and FA by some isolates was so low that it could escape detection. As we found only single isolates showing low production of MON and FA, further studies need to be conducted to clarify this finding. The amounts of FA were low, as reported from other studies [59]. Even though FA exerts low toxicity at levels normally detected in natural infections, synergistic effects have been reported between DON and FA in pigs and FB1 and FA in chicken eggs [60]. Although DON is not produced by the species of the FFSC, both DON and FB1 are common in maize grains and contamination with multiple mycotoxins may occur. FA thus potentially increases the risk of mycotoxin exposure via maize consumption.

In the present study, all strains of F. temperatum and F. subglutinans were FUSA-producers. Even though contamination with FUSA and also BEA are rarely reported in literature [61], a significant role of these toxins in the natural toxicity of the producing species, also in association with other toxins, such as MON, was suggested [16]. The biological activity of FUSA remains to be fully elucidated. We were not able to detect ENNB or ENNA1 in any analyzed rice culture; however, low amounts of ENNB were detected in three maize cobs naturally infected with F. temperatum, harvested in 2017 (data not shown). These maize cobs were co-infected with F. temperatum and F. avenaceum, which was likely responsible for the production of ENNB [6]. Production of any enniatins has shown to be a rare event among isolates of F. temperatum so it may not be considered a mycotoxin characteristic of F. temperatum [19]. Even though the ability to synthesize enniatins is a common feature of some trichothecene producing species of Fusarium, such as F. avenaceum, [6,62] it has rarely been observed for any species of the GFSC [13]. Enniatins are less toxic than trichothecenes, such as deoxynivalenol. Their function in pathogenesis on maize is still unknown.

The production of fumonisins has been reported in a few cases for both F. temperatum and F. subglutinans, even though the associated FUM-cluster could not be detected in their genomes. The production of these toxins by both species in maize plants [35] can be explained by spontaneous infection of the plants with other species. Wang at al. [22] reported production of fumonisins by F. temperarum but because they analyzed grains from the field rather than axenic cultures and have not described the analytical method adequately, their results have not been considered here. We detected fumonisins in only one culture of F. temperatum, likely due to contamination, supporting the current view that F. temperatum does not produce fumonisins. FB1 and FB2 were also detected in one culture of F. subglutinans. Even though F. subglutinans was occasionally reported to produce fumonisins [63], which is a common feature among members of the FFSC, both classical [18] as well as modern studies [64-67] convincingly showed that F. subglutinans does not produce fumonisins. 
Mycotoxin production found in a small set of cultures of $F$. verticillioides and F. proliferatum confirmed the established mycotoxin spectra of these species [59,68-70].

Gene clusters required for synthesis of sphinganine-analog metabolites, such as fumonisins, in Fusarium spp. are conserved [65-67]. Sequence analysis of the gene amplified from F. subglutinans and F. temperatum with primers for the gene FUM1 revealed that the product was unrelated to FUM1. Interestingly, a gene with a high sequence similarity to the product was found in the genome of the closely related species $F$. anthophilum. The amino acid sequence predicted a coiled coil region (Figure 2), possibly indicating involvement of a hypothetical protein in the regulation of gene expression. F. anthophilum is a member of the American clade of the FFSC, which includes fumonisin-nonproducing species F. temperatum and F. subglutinans and fumonisin-producing species F. anthophilum and Fusarium bulbicola [65]. The authors assume a combination of loss of the respective genes during species divergence and horizontal gene transfer, leading to the loss or retention of fumonisin synthesis.

The results obtained in the present study indicate a high degree of variability in BEA, MON, FA, and FUSA production among isolates of F. temperatum. We found isolates with a comparably low toxicity, producing low amounts of FA, BEA, MON, and FUSA, and highly toxic isolates. Our results support the assumption of lower toxigenic risk due to infection of maize with $F$. subglutinans as compared to F. temperatum, especially regarding the production of BEA.

In conclusion, the present investigations indicate that $F$. temperatum occurs more frequently on maize cobs and is more aggressive than previously known, and thus represents an elevated threat of food and feed contamination to growers, processing industries, and consumers. In addition, F. temperatum may enhance the risk of head blight on wheat if grown in rotation with maize.

\section{Materials and Methods}

\subsection{Fungal Isolation and Cultivation}

Fusarium isolates were obtained from 293 naturally infected maize cobs and 190 stalk samples, which were collected from silage and grain maize at 72 field sites in Germany in 2017 and 2018. Thirty randomly chosen kernels of each cob were surface sterilized for $10 \mathrm{~min}$ with $0.1 \%$ silver nitrate and incubated on moist sterile filter paper for two days at room temperature. Afterwards, kernels with outgrowing Fusarium mycelium were placed on potato dextrose agar (PDA) [71]. The rachis was cut in nine slices, three from the base, three from the middle part, and three from the tip of the cob. The slices were surface sterilized as described above and placed directly on PDA plates. The stalk samples were cut in nine slices, three from the first nodium, three from the internodium, and three from the second nodium. The samples were surface sterilized and placed on PDA plates. After two days, Fusarium mycelium outgrown from the sample was transferred to synthetic low nutrition agar (SNA) [71] to produce single spore cultures. The isolates were stored as single spore cultures on synthetic SNA plates at $4{ }^{\circ} \mathrm{C}$. Reference strains of Fusarium (Table S7) were grown at $25^{\circ} \mathrm{C}$ in the dark.

\subsection{Inoculum Preparation}

Spore suspension was produced according to Reid et al. [72] in liquid media containing $2 \mathrm{~g}$ $\mathrm{KH}_{2} \mathrm{PO}_{4}, 2 \mathrm{~g} \mathrm{KNO}_{3}, 1 \mathrm{~g} \mathrm{MgSO}_{4}, 1 \mathrm{~g} \mathrm{KCL}, 1$ g glucose, $2 \mathrm{mg} \mathrm{FeCl}, 0.2 \mathrm{mg} \mathrm{MnSO}_{4}$, and $0.2 \mathrm{mg} \mathrm{ZnSO}$ in $1 \mathrm{~L}$ of water. A plug of agar medium (PDA or SNA) with a diameter of $1 \mathrm{~cm}$ overgrown with mycelium was added to $200 \mathrm{~mL}$ of the autoclaved medium in a $500 \mathrm{~mL}$ Erlenmeyer flask. The medium was placed on a shaker and shaken slowly for 10 days under near-UV-light $(\lambda=440-400 \mathrm{~nm})$. The spore suspension was filtered through gauze and spore concentration was determined with a Thoma hemocytometer. For F. graminearum, spore density was adjusted to $1 \times 10^{4}$ spores per $\mathrm{mL}$. For F. temperatum, F. subglutinans, F. crookwellense, F. culmorum, and F. verticillioides, the inoculum was adjusted to a density of $1 \times 10^{6}$ spores per $\mathrm{mL}$. 


\subsection{Pathogenicity Test on Maize Cobs under Field Conditions}

The field trials in 2018 and 2019 were located at five locations in Germany and France, i.e., Liesborn (North Rhine-Westphalia, Germany), Bernburg (Saxony, Germany), Kuenzing (Bavaria, Germany), and Rustenhart (Gran Est, France). In 2019, an additional field trial was set up in Goettingen. At each location, maize plants of four susceptible varieties were inoculated by silk channel injection and needle pin stabbing with F. graminearum, F. temperatum, and F. verticillioides. Maize plants in Goettingen were inoculated with F. subglutinans instead of F. verticillioides. Plants were grown in a randomized complete block design, with $75 \mathrm{~cm}$ between rows and $13.3 \mathrm{~cm}$ between plants $\left(9\right.$ plants $\left./ \mathrm{m}^{2}\right)$ in two repetitions. The primary ear of ten plants per row was inoculated with the pathogen, whereas another ten cobs were inoculated with water (control). The time point of inoculation was determined individually based on the time point of flowering. Silk channel inoculation was performed by a self-refilling syringe (Socorex 173, Ecublens, Swiss) seven days after 50\% silk emergence in a row. Two $\mathrm{mL}$ of spore suspension were injected into silk channels between the cob tip and the point where silks emerge [72]. Needle pin inoculation was conducted 15 days after silk emergence. Prior to wounding, the four stainless steel needles (18 $\mathrm{mm}$ long, $10 \mathrm{~mm}$ wide) were dipped into the spore suspension and stabbed in the center of the ear through the husk leaves. At physiological maturity, husk leaves of ten Fusarium-inoculated and ten control ears were removed, and disease severity was rated. Disease severity on primary ears was assessed visually as percentage $(0-100 \%)$ of surface covered with mycelium based on the EPPO Guidelines (PP 1/285) [73]. Ten Fusarium inoculated and five water inoculated ears per row were harvested, dried, and shelled (Almaco, IA, USA). Temperature and rainfall data were obtained during the whole vegetation period from a weather station close to the field site $(<5 \mathrm{~km})$.

\subsection{Pathogenicity Test on Maize Stalks under Greenhouse Conditions}

Pathogenicity on maize stalk was tested at two plant growth stages in two separate experiments, after seven weeks (BBCH 13) by toothpick inoculation, and at flowering (BBCH 65) by needle pin inoculation. Toothpick inoculation was adapted from Scauflaire et al. [19]. Six wooden toothpicks per treatment were autoclaved (three times for $15 \mathrm{~min}$ at $121^{\circ} \mathrm{C}$ ) and preserved in $15 \mathrm{~mL}$ tubes with $5 \mathrm{~mL}$ of $2 \%$ malt extract broth medium (Merck, Darmstadt, Germany). Afterwards, $1 \mathrm{~mL}$ of spore suspension of 13 isolates of F. temperatum and seven isolates of F. subglutinans was added to the preserved toothpicks. Following inoculation, toothpicks were incubated for two weeks at $23{ }^{\circ} \mathrm{C}$ in the dark.

Seeds of one maize hybrid were surface sterilized with $0.1 \%$ sodium hypochlorite for $10 \mathrm{~min}$ and sown in $12 \mathrm{~cm}$ diameter pots filled with a mixture of potting soil, compost, and sand (3/1/1). Pots were placed in growth chambers at $22{ }^{\circ} \mathrm{C}, 50 \%$ relative humidity and a day-/night-light cycle of $14 / 10 \mathrm{~h}$. After seven weeks, stalks were inoculated by piercing with a toothpick overgrown with Fusarium $10 \mathrm{~cm}$ above the soil surface. The toothpick was cut at both sides of the stalk surface and the inoculation site sealed with Parafilm ${ }^{\circledR}$. Six plants were inoculated per isolate. After 14 days, plants were collected and the length of necrotic lesions around the inoculation point was measured. Lesion length was measured from the stark surface, then the stalk was cut in two halves and necrosis were measured inside of the stalk.

Pathogenicity testing on maize stalks by needle pin inoculation was conducted at the flowering stage. Maize seeds of four susceptible hybrids were seeded in a mixture of potting soil in $20 \mathrm{~cm}$ diameter pots. Pots were placed in the greenhouse at $23^{\circ} \mathrm{C}$ at a seasonal day-/night-light cycle. Stalks were inoculated with F. graminearum, F. crookwellense, F. culmorum, F. subglutinans, and F. temperatum by dipping the needle pin into the spore suspension and stabbing in the middle of the first elongated internode of the stalk. The insertion point was sealed with Parafilm M (VWR International, Darmstadt, Germany). Ten plants per treatment were inoculated in two repetitions. Six weeks (42 dpi) after inoculation, disease severity was assessed as mentioned earlier. 


\subsection{Effect of Temperature on Ear Infection}

In order to assess and compare the effect of temperature on the aggressiveness of F. subglutinans and F. temperatum on maize, a climate chamber trial was performed. Plants of a susceptible maize hybrid were sown in $16 \mathrm{~cm}$ diameter pots filled with a mixture of potting soil, compost, and sand $(3 / 1 / 1)$ and placed in the greenhouse at seasonal temperature and a day-/night-light cycle until flowering. Plants were inoculated by a syringe (Braun, Melsungen, Germany) with two isolates of F. temperatum (50.2c and 22.4st, Table S1 and Table 4), differing in the mycotoxin profile, and one isolate of F. subglutinans (28.4sp, Table S1 and Table 4), by silk channel inoculation. Inoculation was carried out ten days after silk emergence by injection of $1 \mathrm{~mL}$ spore suspension into the silk channel between the cob tip and the point where silks emerge from the husk. Plants were maintained in separate climate chambers at $12{ }^{\circ} \mathrm{C}, 15^{\circ} \mathrm{C}, 18^{\circ} \mathrm{C}, 21^{\circ} \mathrm{C}$, and $24^{\circ} \mathrm{C}$, with a relative humidity of $70 \%$ and day-/night-light cycle of $14 / 10$ h. Experiments were carried out in duplicates; five plants were inoculated with sterile water and served as control. Plants were harvested six weeks after inoculation and disease severity was scored visually as mentioned before.

\subsection{Pathogenicity Test on Wheat under Greenhouse Conditions}

The pathogenicity of F. temperatum and F. subglutinans in comparison to F. graminearum was examined on two highly susceptible and one less susceptible winter wheat variety. Seedlings were vernalized for seven weeks at $4{ }^{\circ} \mathrm{C}$ and planted in $7 \mathrm{~cm}$ diameter pots filled with potting soil and compost (1/1). Pots were placed in the greenhouse at seasonal temperature and day-/night-light cycle. Plants were inoculated with four isolates of F. temperatum, three isolates of $F$. subglutinans and one isolate of F. graminearum by spray and point inoculation. Ten plants in two repetitions were inoculated with the pathogen and five plants per variety were inoculated with sterile water, which served as control. Point inoculation was conducted with a syringe (Braun, Melsungen, Germany) by injecting $25 \mu \mathrm{L}$ of spore suspension into the center of two florets at anthesis. Spray inoculation was conducted at the beginning of anthesis by spraying $2 \mathrm{~mL}$ spore suspension (same densities as described above) from two sides on cereal heads. Ears were covered with plastic bags for $48 \mathrm{~h} /$ days post inoculation. Severity of infection was scored visually as percentage (0-100\%).

\subsection{DNA Extraction, PCR, Sequencing, and Bioinformatic Analysis}

Mycelium was carefully scrubbed from the surface of PDA culture plates, inoculated with Fusarium spp. obtained from naturally infected maize cobs or reference strains (Table S4), and incubated at $25{ }^{\circ} \mathrm{C}$ in the dark for 5-7 days. DNA was extracted from lyophilized mycelium, using a CTAB-based protocol as described by Brandfass and Karlovsky [74]. Quality and quantity of the extracted DNA were assessed on agarose gels $(0.8 \%(w / v)$ in $1 \times$ Tris-acetate-EDTA buffer) stained with ethidium bromide. Gel electrophoresis was carried out for $60 \mathrm{~min}$ at $4.6 \mathrm{~V} / \mathrm{cm}$.

Species-specific PCR analysis was performed in a CFX384 Thermocycler (Biorad, Ruedigheim, Germany) in 384-well microplates (SARSTEDT AG \& Co. KG, Nuembrecht, Germany) using a total reaction volume of $4 \mu \mathrm{L}$. Reactions were composed of $1 \mu \mathrm{L}$ template DNA or ddH $\mathrm{O}_{2} \mathrm{O}$ for negative controls and $3 \mu \mathrm{L}$ of reaction mixture (Table 7 and $\mathrm{ddH}_{2} \mathrm{O} ; 0.1 X$ SYBR Green I solution (Invitrogen, Karlsruhe, Germany); $1 \mathrm{mg} / \mathrm{mL}$ bovine serum albumin (BSA); $0.025 \mu \mathrm{L}$ of DNA polymerase (Table 7). Individual cycler conditions are summarized in Table 8. All standards as well as the negative control were amplified in duplicates. Following amplification, melting curves were obtained. Samples were heated to $95{ }^{\circ} \mathrm{C}$ for $60 \mathrm{~s}$ and cooled to $55^{\circ} \mathrm{C}$ for $60 \mathrm{~s}$. Afterwards, the temperature was increased from $55^{\circ} \mathrm{C}$ to $69^{\circ} \mathrm{C}$ by $0.5^{\circ} \mathrm{C}$ per cycle with continuous fluorescence measurement. Fluorescent data were obtained during the annealing phase to construct a melting curve at the end of the assay. The PCR was completed by running a melting curve analysis. 
Table 7. Reaction mixtures for species-specific PCR assays.

\begin{tabular}{|c|c|c|c|c|c|}
\hline Target Species & $\mathrm{MgCl}_{2}(\mathrm{mM})$ & Primer $(\mu \mathrm{M})$ & $\operatorname{dNTP}^{1}(\mu \mathrm{M})$ & DNA-Polymerase ${ }^{2}$ & Reaction Buffer ${ }^{1}$ \\
\hline F. temperatum & 2 & 0.3 & 150 & HotStart Taq & Standard Taq ${ }^{3}$ \\
\hline F. subglutinans & 3.5 & 0.3 & 100 & $\mathrm{Taq}$ & ThermoPol ${ }^{\circledR 4}$ \\
\hline F. verticillioides & 2.5 & 0.3 & 100 & $T a q$ & ThermoPol $^{\circledR}$ \\
\hline F. proliferatum & 2 & 0.3 & 125 & Taq & ThermoPol $^{\circledR}$ \\
\hline
\end{tabular}

Table 8. Cycler conditions for species-specific PCR assays.

\begin{tabular}{cccccc}
\hline Target Species & Initial Denaturation & Denaturation & Annealing & Extension & No. of Cycles \\
\hline F. temperatum & $95^{\circ} \mathrm{C}, 120 \mathrm{~s}$ & $94^{\circ} \mathrm{C}, 30 \mathrm{~s}$ & $63^{\circ} \mathrm{C}, 30 \mathrm{~s}$ & $68^{\circ} \mathrm{C}, 30 \mathrm{~s}$ & 35 \\
F. subglutinans & $95^{\circ} \mathrm{C}, 120 \mathrm{~s}$ & $94{ }^{\circ} \mathrm{C}, 30 \mathrm{~s}$ & $65^{\circ} \mathrm{C}, 30 \mathrm{~s}$ & $68^{\circ} \mathrm{C}, 40 \mathrm{~s}$ & 35 \\
F. verticillioides & $95^{\circ} \mathrm{C}, 120 \mathrm{~s}$ & $94{ }^{\circ} \mathrm{C}, 40 \mathrm{~s}$ & $62.5^{\circ} \mathrm{C}, 30 \mathrm{~s}$ & $68^{\circ} \mathrm{C}, 40 \mathrm{~s}$ & 35 \\
F. proliferatum & $95{ }^{\circ} \mathrm{C}, 120 \mathrm{~s}$ & $94{ }^{\circ} \mathrm{C}, 35 \mathrm{~s}$ & $64^{\circ} \mathrm{C}, 30 \mathrm{~s}$ & $68^{\circ} \mathrm{C}, 35 \mathrm{~s}$ & 35 \\
\hline
\end{tabular}

Amplification of partial genes TEF-1 $\alpha$ (694 bp), RPB2 (ca. 763 bp), and FUM1 (1118 bp) were performed in a peqSTAR 96 universal gradient thermocycler (PEQLAB, Erlangen, Germany) using 1:100 $(v / v)$ dilutions of the DNA extract in a total reaction volume of $25 \mu \mathrm{L}$. The TEF-1 $\alpha$ gene was amplified using the primers EF1 and EF2 (Table 9). Partial RPB2 region was amplified with the primers RPB2-5F2 and RPB2-7CR, according to Lofgren et al. [58]. For amplification of the FUM1 gene, we used the primers FUM1F1 and FUM1R2 (Table 1), originally designed for amplification of FUM1 sequences in F. proliferatum [28]. PCR mixtures were composed of Standard Taq reaction buffer (10 $\mathrm{mM}$ Tris- $\mathrm{HCl}, 50 \mathrm{mM} \mathrm{KCl}, 1.5 \mathrm{mM} \mathrm{MgCl} 2, \mathrm{pH} 8.3$ at $25^{\circ} \mathrm{C}$; NEB), $100 \mu \mathrm{M}$ of each deoxyribonucleoside triphosphate, $0.3 \mu \mathrm{M}$ of each primer, $0.62 \mathrm{u}$ HotStart-polymerase (NEB) and $1 \mu \mathrm{L}$ template DNA solution. Final $\mathrm{MgCl}_{2}$ concentration was adjusted to $2 \mathrm{mM}$. PCR conditions for amplification of TEF- $1 \alpha$ were: initial denaturation for $30 \mathrm{~s}$ at $95^{\circ} \mathrm{C} ; 30$ cycles consisting of $30 \mathrm{~s}$ at $94^{\circ} \mathrm{C}, 30 \mathrm{~s}$ at $58^{\circ} \mathrm{C}$, and $1 \mathrm{~min}$ at $68^{\circ} \mathrm{C}$; and final extension for $5 \mathrm{~min}$ at $68^{\circ} \mathrm{C}$. PCR conditions for amplification of FUM1 were: initial denaturation for $30 \mathrm{~s}$ at $95^{\circ} \mathrm{C} ; 35$ cycles consisting of $30 \mathrm{~s}$ at $94{ }^{\circ} \mathrm{C}, 30 \mathrm{~s}$ at $60{ }^{\circ} \mathrm{C}$, and $90 \mathrm{~s}$ at $68^{\circ} \mathrm{C}$; and final extension for $5 \mathrm{~min}$ at $68^{\circ} \mathrm{C}$. The PCR cycling conditions for amplification of $R P B 2$ included an initial denaturation for $30 \mathrm{~s}$ at $95^{\circ} \mathrm{C} ; 10$ cycles consisting of $30 \mathrm{~s}$ at $94^{\circ} \mathrm{C}$, a gradual decrease from $62{ }^{\circ} \mathrm{C}$ to $53{ }^{\circ} \mathrm{C}\left(-1{ }^{\circ} \mathrm{C} /\right.$ cycle $)$ for $40 \mathrm{~s}$, and $1 \mathrm{~min}$ at $68^{\circ} \mathrm{C} ; 30$ cycles of $30 \mathrm{~s}$ at $94{ }^{\circ} \mathrm{C}, 40 \mathrm{~s}$ at $56{ }^{\circ} \mathrm{C}$, and $1 \mathrm{~min}$ at $68^{\circ} \mathrm{C}$; and final extension for $5 \mathrm{~min}$ at $68^{\circ} \mathrm{C}$. All PCR products were purified and sent for Sanger-sequencing to Macrogen Europe (Amsterdam, The Netherlands). Amplicons generated for the FUM1 gene were purified from an agarose gel by using the FastgeneTM Gel/PCR Extraction kit (Nippon Genetics Europe GmbH, Düren, Germany). Results were evaluated with Chromas version 2.6.6 (South Brisbane, Australia) and used for comparative BLAST analysis. Multiple sequence alignment was then performed by using ClustalW [25] in MEGA version 7.0.26 [26]. 
Table 9. Primers used in this study.

\begin{tabular}{|c|c|c|c|c|}
\hline Name & Sequence $\left(5^{\prime}-3^{\prime}\right)$ & Gene & Amplicon Length (bp) & Reference \\
\hline SUB 1 & CTGTCGCTAACCTCTTTATCCA & \multirow[b]{2}{*}{$c a l^{1}$} & \multirow[b]{2}{*}{631} & \multirow[b]{2}{*}{ [23] } \\
\hline SUB 2 & CAGTATGGACGTTGGTATTATATCTAA & & & \\
\hline FtempF & AAGACCTGGCGGGC & \multirow[b]{2}{*}{$T E F-1 \alpha$} & \multirow[b]{2}{*}{296} & \multirow{2}{*}{ [75] } \\
\hline FtempR & TCAGAAGGTTGTGGCAATGG & & & \\
\hline VER 1 & CTTCCTGCGATGTTTCTCC & \multirow[b]{2}{*}{ cal } & \multirow[b]{2}{*}{578} & \multirow[b]{2}{*}{ [23] } \\
\hline VER 2 A & ATTGGCCATTGGTATTATATATCTA & & & \\
\hline Fp3-F & CGGCCACCAGAGGATGTG & \multirow{2}{*}{$i g s^{2}$} & \multirow[b]{2}{*}{230} & \multirow[b]{2}{*}{ [53] } \\
\hline Fp4-R & CAACACGAATCGCTTCCTGAC & & & \\
\hline $\mathrm{EF} 1 \alpha \mathrm{F}$ & ATGGGTAAGGARGACAAGAC & \multirow{2}{*}{$T E F-1 \alpha$} & \multirow{2}{*}{694} & \multirow{2}{*}{ [76] } \\
\hline $\mathrm{EF} 1 \alpha \mathrm{R}$ & GGARGTACCAGTRATCATGTT & & & \\
\hline RPB2-5F2 & GGGGWGAYCAG AAGAAGGC & \multirow{2}{*}{$R P B 2$} & \multirow{2}{*}{1200} & \multirow{2}{*}{ [58] } \\
\hline RPB2-7CR & CCCATRGCTTGYTT RCCCAT & & & \\
\hline FUM1F1 & CACATCTGTGGGCGATCC & \multirow{2}{*}{ FUM1 } & \multirow[b]{2}{*}{1118} & \multirow{2}{*}{ [28] } \\
\hline FUM1R2 & ATATGGCCCCAGCTGCATA & & & \\
\hline
\end{tabular}

\subsection{Mycotoxin Extraction and HPLC-Analysis}

Rice cultures [24] were inoculated with single-spore isolates (SNA, agar plugs of $0.5 \mathrm{~cm}$ diameter) of F. temperatum, F. subglutinans, F. verticillioides, and F. proliferatum obtained from naturally infected maize cobs, and references strain MUCL52463 (Table S4), kindly provided by Dr. Jonathan Scauflaire (Earth and Life Institute, Louvain-la-Neuve, Belgium). Controls were inoculated with blank culture medium. Tubes were incubated in the dark for 28 days, at $21^{\circ} \mathrm{C}$. Mycotoxins were extracted in $30 \mathrm{~mL}$ acetonitrile/water/acetic acid $(84 / 15 / 1(v / v / v))$, following evaporation and sample preparation in methanol/water $(20 / 80(v / v))$ for HPLC-MS/MS, as described elsewhere [77].

Toxin quantification was performed on an Agilent 1290 Infinity II HPLC system coupled to an Agilent 6460 QQQ (Agilent Technologies, Waldbronn, Germany). Samples were analyzed on a Phenomenex Kinetex C18 column with a particle size of $2.5 \mu \mathrm{m}, 100 \AA$ pore size and $50 \times 2.1 \mathrm{~mm}$ (Phenomenex Ltd., Aschaffenburg, Germany). A 12-point calibration ranging from 3.9 to $2000 \mu \mathrm{g} / \mathrm{L}$ was used. Final analysis was performed with MassHunter B.0.8.00 (Agilent, Waldbronn, Germany). The MS/MS transitions, limits of detection (LODs) and limits of quantification (LOQs) are listed in Table S4.

\subsection{Statistical Analysis}

Statistical analysis was conducted using STATISTICA version 13 (Statistica GmbH, Germany). Means of lesion length were estimated for inside and outside of the stalk for each Fusarium species and isolates using the non-parametric Kruskal-Wallis ANOVA and Mann-Whitney-U-Test by 5\% probability. Disease severity of ears and wheat heads were $\log (x+1)$ transformed to normalized data. Analysis of variance (ANOVA) for field and greenhouse experiments were carried out by Tukey-HSD-test at $5 \%$ probability. Thousand-kernel-weight (TKW) was analyzed by ANOVA and Tukey-Test at $5 \%$ probability.

Supplementary Materials: The following are available online at http://www.mdpi.com/2076-0817/9/11/864/s1. Figure S1: Sampling locations. Figure S2: Molecular phylogenetic analysis of DNA-directed RNA polymerase II subunit (RPB2). Table S1: List of isolates of F. temperatum and F. subglutinans and selected isolates of F. proliferatum and F. verticillioides. Table S2: Analysis of variance from maize cob inoculation under field conditions. Table S3. Analysis of variance from maize cob inoculation at greenhouse conditions at five different temperatures. Table S4: Sequence variations of partial TEF-1 $\alpha$ gene in isolates of F. temperatum. Reference strains of Fusarium used in this study. Table S5: Accession numbers of reference sequences used in phylogenetic analysis of $T E F-1 \alpha, R P B 2$, and FUM1. HPLC-MS/MS analysis. Table S6: Specification of HPLC-MS/MS analysis. Table S7: Reference strains of Fusarium.

Author Contributions: Conceptualization, A.P., S.S., A.v.T., and P.K.; methodology, A.P., C.R., M.B., N.B., S.S., and A.R.; software, A.P., S.S., C.R., M.B., N.B., and A.R.; validation, A.P., C.R., M.B., N.B., S.S., and A.R.; formal analysis, A.P., S.S., and A.R.; investigation, A.P., S.S., A.R., A.v.T., and P.K.; resources, A.v.T. and P.K.; data curation, A.P. and S.S.; writing-original draft preparation, A.P. and S.S.; writing-reviewing and editing, 
A.P., S.S., A.R., A.v.T., and P.K.; visualization, A.P. and S.S.; supervision, P.K. and A.v.T.; project administration, A.v.T. and P.K.; funding acquisition, A.v.T. and P.K. All authors have read and agreed to the published version of the manuscript.

Funding: This research was funded by the German Federal Office for Agriculture and Food (BLE), grant number 2818208315.

Acknowledgments: The authors would like to thank Brigitte Jünemann and Luciana Macis for technical support, Franz Berthiller (BOKU, Tulln, Austria) for analytical standard for fusaproliferin and Jonathan Scauflaire (Earth and Life Institute, Louvain-la-Neuve, Belgium) for providing us with reference strains of F. temperatum.

Conflicts of Interest: The authors declare no conflict of interest. The funders had no role in the design of the study; in the collection, analyses, or interpretation of data; in the writing of the manuscript, or in the decision to publish the results.

\section{References}

1. Munkvold, G.P. Epidemiology of Fusarium diseases and their mycotoxins in maize ears. Eur. J. Plant Pathol. 2003, 109, 705-713. [CrossRef]

2. Desjardins, A.E.; Maragos, C.M.; Proctor, R.H. Maize ear rot and moniliformin contamination by cryptic species of Fusarium subglutinans. J. Agric. Food Chem. 2006, 54, 7383-7390. [CrossRef] [PubMed]

3. Bryła, M.; Waśkiewicz, A.; Ksieniewicz-Woźniak, E.; Szymczyk, K.; Jędrzejczak, R. Modified Fusarium mycotoxins in cereals and their products-metabolism, occurrence, and toxicity: An updated review. Molecules 2018, 23, 963. [CrossRef] [PubMed]

4. Thompson, M.E.H.; Raizada, M.N. Fungal pathogens of maize gaining free passage along the silk road. Pathogens 2018, 7, 81. [CrossRef] [PubMed]

5. Duncan, K.E.; Howard, R.J. Biology of maize kernel infection by Fusarium verticillioides. Mol. Plant Microbe Interact. 2010, 23, 6-16. [CrossRef]

6. Logrieco, A.; Mulé, G.; Moretti, A.; Bottalico, A. Toxigenic Fusarium species and mycotoxins associated with maize ear rot in Europe. Eur. J. Plant Pathol. 2002, 108, 597-609. [CrossRef]

7. Alheeti, A.; Caldwell, R.; Smalley, E. Pathogenicity of Fusarium tricinctum, Fusarium poae and Fusarium sporotrichioides in maize ears. PhytoPathology 1984, 74, 145-156.

8. Chelkowski, J.; Lew, H.; Pettersson, H. Fusarium poae (Peck) Wollenw.-Occurrence in maize ears, nivalenol production and mycotoxin accumulation in cobs. Mycotoxin Res. 1994, 10, 116-120. [CrossRef]

9. Stępień, Ł.; Gromadzka, K.; Chełkowski, J.; Basińska-Barczak, A.; Lalak-Kańczugowska, J. Diversity and mycotoxin production by Fusarium temperatum and Fusarium subglutinans as causal agents of pre-harvest Fusarium maize ear rot in Poland. J. Appl. Genet. 2018, 60, 113-121. [CrossRef]

10. Scauflaire, J.; Gourgue, M.; Munaut, F. Fusarium temperatum sp. nov. from maize, an emergent species closely related to Fusarium subglutinans. Mycologia 2011, 103, 586-597. [CrossRef]

11. Nelson, P.E.; Toussoun, T.A.; Marasas, W.F.O. (Eds.) Fusarium Species: An Illustrated Manual for Identification; The Pennsylvania State University Press: University Park, PA, USA, 1981.

12. Steenkamp, E.T.; Wingfield, B.D.; Desjardins, A.E.; Marasas, W.F.O.; Wingfield, M.J. Cryptic speciation in Fusarium subglutinans. Mycologia 2002, 94, 1032-1035. [CrossRef] [PubMed]

13. Moretti, A.; Mulé, G.; Ritieni, A.; Láday, M.; Stubnya, V.; Hornok, L.; Logrieco, A. Cryptic subspecies and beauvericin production by Fusarium subglutinans from Europe. Int. J. Food Microbiol. 2008, 127, 312-315. [CrossRef] [PubMed]

14. Gupta, S.; Krasnoff, S.B.; Underwood, N.L.; Renwick, J.A.; Roberts, D.W. Isolation of beauvericin as an insect toxin from Fusarium semitectum and Fusarium moniliforme var. subglutinans. Mycopathologia 1991, 115, 185-189. [CrossRef] [PubMed]

15. Krska, R.; Lemmens, M.; Schuhmacher, R.; Grasserbauer, M.; Pronczuk, M.; Wisniewska, H.; Chelkowski, J. Accumulation of the mycotoxin beauvericin in kernels of corn hybrids inoculated with Fusariumsubglutinans. J. Agric. Food Chem. 1996, 44, 3665-3667. [CrossRef]

16. Logrieco, A.; Moretti, A.; Fornelli, F.; Fogliano, V.; Ritieni, A.; Caiaffa, M.F.; Randazzo, G.; Bottalico, A.; Macchia, L. Fusaproliferin production by Fusarium subglutinans and its toxicity to Artemia salina, SF-9 insect cells, and IARC/LCL 171 human B lymphocytes. Appl. Environ. Microbiol. 1996, 62, 3378-3384. [CrossRef]

17. Marasas, W.F.O.; Thiel, P.G.; Rabie, C.J.; Nelson, P.E.; Toussoun, T.A. Moniliformin production in Fusarium section liseola. Mycologia 1986, 78, 242-247. [CrossRef] 
18. Nelson, P.E.; Plattner, R.D.; Shackelford, D.D.; Desjardins, A.E. Fumonisin B1 production by Fusarium species other than F. moniliforme in section liseola and by some related species. Appl. Environ. Microbiol. 1992, 58, 984-989. [CrossRef]

19. Scauflaire, J.; Gourgue, M.; Callebaut, A.; Munaut, F. Fusarium temperatum, a mycotoxin-producing pathogen of maize. Eur. J. Plant Pathol. 2012, 133, 911-922. [CrossRef]

20. Fumero, M.V.; Reynoso, M.M.; Chulze, S. Fusarium temperatum and Fusarium subglutinans isolated from maize in Argentina. Int. J. Food Microbiol. 2015, 199, 86-92. [CrossRef]

21. Varela, C.P.; Casal, O.A.; Padin, M.C.; Martinez, V.F.; Oses, M.J.S.; Scauflaire, J.; Munaut, F.; Castro, M.J.B.; Vázquez, J.P.M. First report of Fusarium temperatum causing seedling blight and stalk rot on maize in Spain. Plant Disease 2013, 97, 1252-1259. [CrossRef]

22. Wang, J.-H.; Zhang, J.-B.; Li, H.-P.; Gong, A.-D.; Xue, S.; Agboola, R.S.; Liao, Y.-C. Molecular identification, mycotoxin production and comparative pathogenicity of Fusarium temperatum isolated from maize in China. J. PhytoPathology 2014, 162, 147-157. [CrossRef]

23. Mulé, G.; Susca, A.; Stea, G.; Moretti, A. A species-specific PCR assay based on the calmodulin partial gene for identification of Fusarium verticillioides. F. proliferatum and F. subglutinans. Eur. J. Plant Pathol. 2004, 110, 495-502. [CrossRef]

24. Nutz, S.; Döll, K.; Karlovsky, P. Determination of the LOQ in real-time PCR by receiver operating characteristic curve analysis: Application to qPCR assays for Fusarium verticillioides and F. proliferatum. Anal. Bioanal. Chem. 2011, 401, 717-726. [CrossRef]

25. Thompson, J.D.; Higgins, D.G.; Gibson, T.J. CLUSTAL W: Improving the sensitivity of progressive multiple sequence alignment through sequence weighting, position-specific gap penalties and weight matrix choice. Nucleic Acid Res. 1994, 22, 4673-4680. [CrossRef]

26. Kumar, S.; Stecher, G.; Tamura, K. MEGA7: Molecular evolutionary genetics analysis version 7.0 for bigger datasets. Mol. Biol. Evol. 2016, 33, 1870-1874. [CrossRef] [PubMed]

27. Tamura, K.; Nei, M. Estimation of the number of nucleotide substitutions in the control region of mitochondrial DNA in humans and chimpanzees. Mol. Biol. Evol. 1993, 10, 512-526.

28. Stępień, L.; Koczyk, G.; Waśkiewicz, A. FUM cluster divergence in fumonisins-producing Fusarium species. Fungal Biol. 2011, 115, 112-123. [CrossRef]

29. Brown, D.W.; Butchko, R.A.E.; Busman, M.; Proctor, R.H. The Fusarium verticillioides FUM gene cluster encodes a $\mathrm{Zn}(\mathrm{II}) 2 \mathrm{Cys} 6$ protein that affects FUM gene expression and fumonisin production. Eukaryot. Cell 2007, 6, 1210-1218. [CrossRef]

30. Altschul, S.F.; Madden, T.L.; Schäffer, A.A.; Zhang, J.; Zhang, Z.; Miller, W.; Lipman, D.J. Gapped BLAST and PSI-BLAST: A new generation of protein database search programs. Nucleic Acids Res. 1997, 25, 3389-3402. [CrossRef]

31. Letunic, I.; Bork, P. 20 years of the SMART protein domain annotation resource. Nucleic Acids Res. 2018, 46, D493-D496. [CrossRef]

32. Madeira, F.; Park, Y.M.; Lee, J.; Buso, N.; Gur, T.; Madhusoodanan, N.; Basutkar, P.; Tivey, A.R.N.; Potter, S.C.; Finn, R.D.; et al. The EMBL-EBI search and sequence analysis tools APIs in 2019. Nucleic Acids Res. 2019, 47, W636-W641. [CrossRef] [PubMed]

33. Czembor, E.; Stępień, Ł.; Waśkiewicz, A. Effect of environmental factors on Fusarium species and associated mycotoxins in maize grain grown in Poland. PLoS ONE 2015, 10, e0133644. [CrossRef] [PubMed]

34. Boutigny, A.-L.; Scauflaire, J.; Ballois, N.; Ioos, R. Fusarium temperatum isolated from maize in France. Eur. J. Plant Pathol. 2017, 148, 997-1001. [CrossRef]

35. Tagele, S.; Kim, S.; Lee, H.; Lee, Y. Aggressiveness and fumonisins production of Fusarium subglutinans and Fusarium temperatum on Korean maize cultivars. Agronomy 2019, 9, 88. [CrossRef]

36. Sutton, J.C.; Baliko, W.; Funnell, H.S. Relation of weather variables to incidence of zearalenone in corn in southern Ontario. Can. J. Plant Sci. 1980, 60, 149-155. [CrossRef]

37. Mansfield, M.A.; De Wolf, E.D.; Kuldau, G.A. Relationships between weather conditions, agronomic practices, and fermentation characteristics with deoxynivalenol content in fresh and ensiled maize. Plant Disease 2005, 89, 1151-1157. [CrossRef]

38. Pfordt, A.; Ramos Romero, L.; Schiwek, S.; Karlovsky, P.; Von Tiedemann, A. Impact of environmental conditions and agronomic practices on the prevalence of Fusarium species associated with ear- and stalk rot in maize. Pathogens 2020, 9, 236. [CrossRef] 
39. Marín, S.; Sanchis, V.; Magan, N. Water activity, temperature, and pH effects on growth of Fusarium moniliforme and Fusarium proliferatum isolates from maize. Can. J. Microbiol. 1995, 41, 1063-1070. [CrossRef]

40. Bacon, C.W.; Hinton, D.M. Symptomless endophytic colonization of maize by Fusarium moniliforme. Can. J. Bot. 1995, 74, 1195-1202. [CrossRef]

41. Munkvold, G.P.; Hellmich, R.L.; Showers, W.B. Reduced Fusarium ear rot and symptomless infection in kernels of maize genetically engineered for European corn borer resistance. PhytoPathology 1997, 87, 1071-1077. [CrossRef]

42. Murillo-Williams, A.; Munkvold, G.P. Systemic infection by Fusarium verticillioides in maize plants grown under three temperature regimes. Plant Disease 2008, 92, 1695-1700. [CrossRef] [PubMed]

43. Munkvold, G.P.; McGee, D.C.; Carlton, W.M. Importance of different pathways for maize kernel infection by Fusarium moniliforme. PhytoPathology 1997, 87, 209-217. [CrossRef] [PubMed]

44. Levic, J.; Munaut, F.; Scauflaire, J.; Stanković, S.; Ivanovic, D.; Krnjaja, V. Pathogenicity of Fusarium temperatum and Fusarium subglutinans on maize stalk and ear under artificial inoculation under field conditions. In Proceedings of the 12th European Fusarium Seminar, Bordeaux, France, 16 May 2013.

45. Maiorano, A.; Blandino, M.; Reyneri, A.; Vanara, F. Effects of maize residues on the Fusarium spp. infection and deoxynivalenol (DON) contamination of wheat grain. Crop Prot. 2008, 27, 182-188. [CrossRef]

46. Blandino, M.; Pilati, A.; Reyneri, A.; Scudellari, D. Effect of maize crop residue density on Fusarium head blight and on deoxynivalenol contamination of common wheat grains. Cereal Res. Commun. 2010, 38, 550-559. [CrossRef]

47. Xu, X.-M.; Parry, D.W.; Nicholson, P.; Thomsett, M.A.; Simpson, D.; Edwards, S.G.; Cooke, B.M.; Doohan, F.M.; Monaghan, S.; Moretti, A.; et al. Within-field variability of Fusarium head blight pathogens and their associated mycotoxins. Eur. J. Plant. Pathol. 2008, 120, 21-34. [CrossRef]

48. Bottalico, A.; Perrone, G. Toxigenic Fusarium species and mycotoxins associated with head blight in small-grain cereals in Europe. Eur. J. Plant Pathol. 2002, 108, 611-624. [CrossRef]

49. Bottalico, A. Fusarium diseases of cereals: Species complex and related mycotoxin profiles in Europe. J. Plant Pathol. 1998, 80, 85-103.

50. Gorczyca, A.; Oleksy, A.; Gala-Czekaj, D.; Urbaniak, M.; Laskowska, M.; Waśkiewicz, A.; Steepień, Ł. Fusarium head blight incidence and mycotoxin accumulation in three durum wheat cultivars in relation to sowing date and density. Sci. Nat. 2018, 105, 2-12. [CrossRef]

51. Guo, Z.; Pfohl, K.; Karlovsky, P.; Dehne, H.-W.; Altincicek, B. Fumonisin B1 and beauvericin accumulation in wheat kernels after seed-borne infection with Fusarium proliferatum. Agric. Food Sci. 2016, 25, 138-145. [CrossRef]

52. Amato, B.; Pfohl, K.; Tonti, S.; Nipoti, P.; Dastjerdi, R.; Pisi, A.; Karlovsky, P.; Prodi, A. Fusarium proliferatum and fumonisin B1 co-occur with Fusarium species causing Fusarium Head Blight in durum wheat in Italy. J. Appl. Bot. Food Qual. 2015, 88, 228-233.

53. Jurado, M.; Vázquez, C.; Marín, S.; Sanchis, V.; Teresa González-Jaén, M. PCR-based strategy to detect contamination with mycotoxigenic Fusarium species in maize. Syst. Appl. Microbiol. 2006, 29, 681-689. [CrossRef] [PubMed]

54. Gromadzka, K.; Błaszczyk, L.; Chełkowski, J.; Waśkiewicz, A. Occurrence of mycotoxigenic Fusarium species and competitive fungi on preharvest maize ear rot in Poland. MDPI Toxins 2019, 11, 224. [CrossRef]

55. Shin, J.-H.; Han, J.-H.; Lee, J.K.; Kim, K.S. Characterization of the maize stalk rot pathogens Fusarium subglutinans and F. temperatum and the effect of fungicides on their mycelial growth and colony formation. Plant Pathol. J. 2014, 30, 397-406. [CrossRef] [PubMed]

56. Robles-Barrios, K.F.; Medina-Canales, M.G.; Rodríguez-Tovar, A.V.; Pérez, N.O. Morphological and molecular characterization, enzyme production and pathogenesis of Fusarium temperatum on corn in Mexico. Can. J. Plant Pathol. 2015, 37, 495-505. [CrossRef]

57. O’Donnell, K.; McCormick, S.P.; Busman, M.; Proctor, R.H.; Ward, T.J.; Doehring, G.; Geiser, D.M.; Alberts, J.F.; Rheeder, J.P.; Marasas, W.; et al. 1984 “Toxigenic Fusarium species: Identity and mycotoxicology” revisited. Mycologia 2018, 110, 1058-1080. [CrossRef] [PubMed]

58. Lofgren, L.A.; LeBlanc, N.R.; Certano, A.K.; Nachtigall, J.; LaBine, K.M.; Riddle, J.; Broz, K.; Dong, Y.; Bethan, B.; Kafer, C.W.; et al. Fusarium graminearum: Pathogen or endophyte of North American grasses? New Phytol. 2018, 217, 1203-1212. [CrossRef] [PubMed] 
59. Bacon, C.W.; Porter, J.K.; Norred, W.P.; Leslie, J.F. Production of fusaric acid by Fusarium species. Appl. Environ. Microbiol. 1996, 62, 4039-4043. [CrossRef]

60. D'Mello, J.P.F.; Placinta, C.M.; Macdonald, A.M.C. Fusarium mycotoxins: A review of global implications for animal health, welfare and productivity. Anim. Feed Sci. Technol. 1999, 80, 183-205. [CrossRef]

61. Jestoi, M. Emerging Fusarium-mycotoxins fusaproliferin, beauvericin, enniatins, and moniliformin: A review. Crit. Rev. Food Sci. Nutr. 2008, 48, 21-49. [CrossRef]

62. Kristensen, R.; Torp, M.; Kosiak, B.; Holst-Jensen, A. Phylogeny and toxigenic potential is correlated in Fusarium species as revealed by partial translation elongation factor 1 alpha gene sequences. Mycol. Res. 2005, 109, 173-186. [CrossRef]

63. Desjardins, A.E. Fusarium Mycotoxins: Chemistry, Genetics and Biology; APS Press: St. Paul, MN, USA, 2006; ISBN 978-0-89054-335-1.

64. Fumero, M.V.; Villani, A.; Susca, A.; Haidukowski, M.; Cimmarusti, M.T.; Toomajian, C.; Leslie, J.F.; Chulze, S.N.; Moretti, A. Fumonisin and Beauvericin chemotypes and genotypes of the sister species Fusarium subglutinans and Fusarium temperatum. Appl. Environ. Microbiol. 2020, 86, 56-63. [CrossRef]

65. Kim, H.S.; Lohmar, M.S.; Busman, M.; Brown, D.W.; Naumann, T.A.; Divon, H.H.; Proctor, R.H. Identification and distribution of gene clusters required for synthesis of sphingolipid metabolism inhibitors in diverse species of the filamentous fungus Fusarium. BMC Genom. 2020, 21, 511.

66. Proctor, R.H.; Van Hove, F.; Susca, A.; Stea, G.; Busman, M.; Van der Lee, T.; Waalwijk, C.; Moretti, A.; Ward, T.J. Birth, death and horizontal transfer of the fumonisin biosynthetic gene cluster during the evolutionary diversification of Fusarium. Mol. Microbiol. 2013, 90, 290-306. [PubMed]

67. Proctor, R.H.; Desjardins, A.E.; Plattner, R.D.; Hohn, T.M. A polyketide synthase gene required for biosynthesis of fumonisin mycotoxins in Gibberella fujikuroi mating population A. Fungal Genet. Biol. 1999, 27, 51-58. [CrossRef] [PubMed]

68. Reyes-Velázquez, W.P.; Figueroa-Gómez, R.M.; Barberis, M.; Reynoso, M.M.; Rojo, F.G.A.; Chulze, S.N.; Torres, A.M. Fusarium species (section Liseola) occurrence and natural incidence of beauvericin, fusaproliferin and fumonisins in maize hybrids harvested in Mexico. Mycotoxin Res. 2011, 27, 187-194. [CrossRef] [PubMed]

69. Glenn, A.E. Mycotoxigenic Fusarium species in animal feed. Anim. Feed Sci. Technol. 2007, 137, 213-240. [CrossRef]

70. Bacon, C.W.; Hinton, D.M.; Porter, J.K.; Glenn, A.E.; Kuldau, G. Fusaric acid, a Fusarium verticillioides metabolite, antagonistic to the endophytic biocontrol bacterium Bacillus mojavensis. Can. J. Bot. 2004, 82, 878-885. [CrossRef]

71. Leslie, J.; Summerell, B.A. Fusarium Laboratory Manual; Blackwell: Oxford, UK, 2006.

72. Reid, L.M.; Bolton, A.T.; Hamilton, R.I.; Woldemariam, T.; Mather, D.E. Effect of silk age on resistance of maize to Fusarium graminearum. Can. J. Plant Pathol. 1992, 14, 293-298. [CrossRef]

73. EPPO PP 1/285. PP 1/285 (1): Fusarium Ear Rot of Maize; EPPO: Paris, France, 2015; Volume 45, pp. $336-339$.

74. Brandfass, C.; Karlovsky, P. Upscaled CTAB-based DNA extraction and real-time PCR assays for Fusarium culmorum and F. graminearum DNA in plant material with reduced sampling error. Int. J. Mol. Sci. 2008, 9, 2306-2321. [CrossRef]

75. Scauflaire, J.; Godet, M.; Gourgue, M.; Liénard, C.; Munaut, F. A multiplex real-time PCR method using hybridization probes for the detection and the quantification of Fusarium proliferatum, F. subglutinans, F. temperatum, and F. verticillioides. Fungal Biol. 2012, 116, 1073-1080. [CrossRef]

76. O’Donnell, K.; Kistler, H.C.; Cigelnik, E.; Ploetz, R.C. Multiple evolutionary origins of the fungus causing Panama disease of banana: Concordant evidence from nuclear and mitochondrial gene genealogies. Proc. Natl. Acad. Sci. USA 1998, 95, 2044-2049. [CrossRef] [PubMed]

77. Beule, L.; Lehtsaar, E.; Rathgeb, A.; Karlovsky, P. Crop diseases and mycotoxin accumulation in temperate agroforestry systems. Sustainability 2019, 11, 2925. [CrossRef]

Publisher's Note: MDPI stays neutral with regard to jurisdictional claims in published maps and institutional affiliations. 